\title{
Wetland and Hydric Soils
}

\author{
Carl C. Trettin, Randall K. Kolka, Anne S. Marsh, \\ Sheel Bansal, Erik A. Lilleskov, Patrick Megonigal, \\ Marla J. Stelk, Graeme Lockaby, David V. D'Amore, \\ Richard A. MacKenzie, Brian Tangen, Rodney Chimner, \\ and James Gries
}

\section{Introduction}

Soil and the inherent biogeochemical processes in wetlands contrast starkly with those in upland forests and rangelands. The differences stem from extended periods of anoxia, or the lack of oxygen in the soil, that characterize wetland soils; in contrast, upland soils are nearly always oxic. As a result, wetland soil biogeochemistry is characterized by anaerobic processes, and wetland vegetation exhibits specific adaptations to grow under these conditions. However, many wetlands may also have periods during the year where the soils are unsaturated and aerated. This fluctuation between aerated and nonaerated soil conditions, along with the specialized vegetation, gives rise to a wide variety of highly valued ecosystem services.

Wetlands were once considered unproductive lands that were a barrier to agricultural, transportation, and urban development. As a result, approximately $53 \%$ of the wetlands in the

C. C. Trettin $(\bowtie)$

U.S. Department of Agriculture, Forest Service, Southern Research Station, Cordesville, SC, USA

e-mail: Carl.trettin@usda.gov

R. K. Kolka

U.S. Department of Agriculture, Forest Service, Northern Research Station, Center for Research on Ecosystem Change, Grand Rapids, MN, USA

\section{A. S. Marsh}

U.S. Department of Agriculture, Forest Service, Research and Development, Bioclimatology and Climate Change Research, Washington, DC, USA

S. Bansal

U.S. Geological Survey, Jamestown, ND, USA

E. A. Lilleskov

U.S. Department of Agriculture, Forest Service, Northern Research Station, Climate, Fire and Carbon Cycle Sciences,

Houghton, MI, USA

P. Megonigal

Smithsonian Institute, Smithsonian Environmental Research

Center, Edgewater, MD, USA conterminous United States have been converted to other land uses over the past 150 years (Dahl 1990). Most of those losses are due to draining and conversion to agriculture. States in the Midwest such as Iowa, Illinois, Missouri, Ohio, and Indiana have lost more than $85 \%$ of their original wetlands, and California has lost $96 \%$ of its wetlands. In the mid-1900s, the importance of wetlands in the landscape started to be understood, and wetlands are now recognized for their inherent value that is realized through the myriad of ecosystem services, including storage of water to mitigate flooding, filtering water of pollutants and sediment, storing and sequestering carbon $(\mathrm{C})$, providing critical habitat for wildlife, and recreation.

Historically, drainage of wetlands for agricultural development has been the largest threat to wetlands. While conversion to agriculture still persists, currently the primary threat is from urbanization (US EPA 2016). The current rate of wetland loss is approximately 23 times less than historic

M. J. Stelk

Association of State Wetland Managers, Windham, ME, USA

G. Lockaby

School of Forestry \& Wildlife, Auburn University,

Auburn, AL, USA

D. V. D'Amore

U.S. Department of Agriculture, Forest Service, Pacific Northwest Research Station, Juneau, AK, USA

R. A. MacKenzie

U.S. Department of Agriculture, Forest Service, Pacific Southwest Research Station, Institute of Pacific Islands Forestry, Hilo, HI, USA

B. Tangen

U.S. Geological Survey, Northern Prairie Wildlife Research Center, Lincoln, NE, USA

R. Chimner

School of Forest Resources and Environmental Science, Michigan Technological University, Houghton, MI, USA

J. Gries

U.S. Department of Agriculture, Forest Service, Eastern Region, Milwaukee, WI, USA 
rates, with wetland restoration and creation nearly offsetting current losses (US FWS 2011). Changes in precipitation patterns and extreme events may affect wetlands, especially those with perched water tables and those along the coast (Amatya et al. 2016). The combination of warming temperatures and variable precipitation, most notably lower precipitation, may lead to the drying of wetlands, which could dramatically change vegetation communities and soil processes and reduce the ability of wetlands to sustain valued ecosystem services.

\section{Goods and Services Derived from Wetlands}

In addition to basic ecosystem functions, wetlands also provide valued goods and services (Sarukhán et al. 2005). Those benefits depend on factors such as hydrology, vegetation, soils, and the condition of the wetland, as well as the position of the wetland within the landscape (Brander et al. 2006; Woodward and Wui 2001). De Groot and others (2012) estimated the mean global value of coastal and inland wetlands at $\$ 193,845 \mathrm{ha}^{-1}$ year $^{-1}$ and $\$ 25,682 \mathrm{ha}^{-1}$ year ${ }^{-1}$, respectively. Higher inland wetland values were found in areas with high gross domestic product and population density, indicating a particular demand for services in these areas. Many values are external to markets and are considered a public good that cannot be traded; however, C storage is a service that has been commoditized. Soils are integral to the provision of ecosystem services, and hence, the derived value. Water supply, water quality, habitat, and provision of goods are major ecosystem services that are sensitive to soils and soil processes.

\section{Water Storage and Supply}

The geographic setting of the wetland and soil type affect water storage, flood control, and mediation of water supply. Riverine wetlands can store floodwaters temporarily, which lessens streamflow to downstream areas and reduces flood events (Hey et al. 2002). Wetland vegetation intercepts and slows water flowing through the wetland and takes up water through transpiration (Vepraskas and Craft 2016). In coastal areas, wetland vegetation can dissipate wave energy from major storm events (e.g., hurricanes, tsunamis) and, in the case of mangroves (Avicennia spp.), protect against wind damage during storms (Das and Crepin 2013; Gedan et al. 2011; Koch et al. 2009; Spaulding et al. 2014). It is estimated that because of wetlands, as much as $\$ 625$ million in damages were avoided during Hurricane Sandy (Narayan et al. 2017). In addition, wetlands connected to groundwater may recharge or discharge critical water resources, a particularly important function in wetlands in dry regions with limited surface water connectivity (Van der Kamp and Hayashi 1998).

\section{Water Quality}

Eutrophication is the over-enrichment of water by nutrients and other pollutants that can result in excessive algal blooms. Because wetlands have both anaerobic and aerobic biogeochemical soil processes, they can be effective at ameliorating nutrient runoff, thereby reducing the risk of eutrophication (Hemond and Beniot 1988; Johnston et al. 1990). Microbialmediated processes are the principal mechanism affecting nutrients and pollutants in runoff. Plant structures such as stems, roots, or trunks provide structural support for microbes, and direct uptake by vegetation is also a mechanism affecting nutrient and pollutant removal (Furukawa et al. 1997; Gosselink and Turner 1978). Removal of excessive nitrogen $(\mathrm{N})$ is particularly important since it is a common constituent in runoff from agriculture and urban lands. As nitrate, $\mathrm{N}$ can be removed through denitrification; the microbial transformation to $\mathrm{N}$ gas (Reddy et al. 1989). In contrast, phosphate may be complexed to iron and aluminum minerals by chemical reactions (Smil 2000). Suspended sediment particles in water flowing through wetlands settle out of the water column as water flow slows, and these sediments are then trapped by plant stems, roots, and trunks (Furukawa et al. 1997; Gosselink and Turner 1978). The water purification processes of wetlands have been engineered into constructed wetlands that are used to treat municipal wastewater (Kadlec and Wallace 2009; Vymazal 2011).

\section{Carbon}

Wetland soils are a natural sink for $\mathrm{C}$, and per unit area they store much more $\mathrm{C}$ than upland soils. This is especially true for organic soils that globally store approximately $30 \%$ of soil C on approximately $3 \%$ of the land area (Page et al. 2011). Similarly, mangroves can store three to five times more $\mathrm{C}$ than temperate or tropical forest soils (Alongi 2014; Donato et al. 2012). Accordingly, the value of wetlands for $C$ storage, and thus climate change mitigation, is widely recognized. The ability of wetlands to store large amounts of soil $\mathrm{C}$ is due in part to high plant productivity that removes carbon dioxide $\left(\mathrm{CO}_{2}\right)$ from the atmosphere (Kolka et al. 2018; Nahlik and Fennessy 2016; Schuur et al. 2015; WindhamMyers et al. 2018) and the decomposition of plant matter that is hindered by the lack of oxygen, which results in the accumulation of organic C (Mcleod et al. 2011). In some freshwater wetlands, the production of methane $\left(\mathrm{CH}_{4}\right)$ and nitrous oxide $\left(\mathrm{N}_{2} \mathrm{O}\right)$, two gases with a greater greenhouse gas warming potential than $\mathrm{CO}_{2}$, can partially or fully offset this climate mitigation capacity (Bridgham et al. 2013; Mitsch et al. 2013; Neubauer 2014; Smith et al. 2003).

\section{Wildlife Habitat}

Wetlands support almost half of the threatened and endangered species in the United States, as well as commercially valuable species of fish and shellfish, and mammals trapped 
for pelts (Flynn 1996; Niering 1988). Wetland soils provide important habitat for benthic algae and invertebrates that are an important food resource for many resident and migratory birds and fish (Currin et al. 1995; MacKenzie 2005; MacKenzie and Dionne 2008; MacKenzie et al. 2015). Other wetland species that feed on wetland soil resources are valued for recreational purposes (Bergstrom et al. 1990; Creel and Loomis 1992; Jenkins et al. 2010). For example, the Prairie Pothole Region, which extends across the northern Great Plains into Canada, provides breeding habitat for 50-80\% of waterfowl in North America (Batt et al. 1989). Wetlands are particularly popular locations for fishing, birdwatching, and hunting. Because of their open spaces and natural vegetation, wetlands are also often valued for their aesthetics, which can increase nearby property values (Doss and Taff 1996; Frey et al. 2013; Mahan et al. 2000).

\section{Commodities}

Wetlands provide marketable goods. Wetland soils can be highly productive for agriculture and silviculture, but the intensity of management may affect other ecosystem services, and excessive drainage can result in wetland loss (Dahl 2011). In the United States, approximately $6500 \mathrm{~km}^{2}$ of organic soil wetlands are being used for crop production (ICF International 2013). Intensive silviculture in wetlands is most common in the southeastern United States, where species such as loblolly pine (Pinus taeda), cypress (Taxodium spp.), and black gum (Nyssa sylvatica) are harvested for lumber, mulch, pulpwood, and other purposes (Beauchamp 1996; Wear and Greis 2002). Forested wetlands are also managed in the Great Lakes region, and wetlands support commercial and recreational fisheries, including both fish and shellfish (Feierabend and Zelazny 1987; LellisDibble et al. 2008).

\section{Objective and Scope}

In this chapter, we consider organic and mineral soil wetlands in the United States and its Island Territories that are forested or nonforested in tidal and nontidal settings. This chapter does not consider constructed wetlands (e.g., wastewater treatment systems or stormwater detention basins) or lakes and rivers. We synthesize the state of wetland soil science relative to ecosystem functions that regulate valued ecosystem services. We build on volumes dedicated to wetlands (e.g., Mitsch and Gosselink 2015) and wetland soils (e.g., Richardson and Vepraskas 2001) to assess the role of soils in wetland processes and to identify information and tools to address threats posed to the sustainability of ecosystem services provided by wetlands. Because wetlands are so different from upland forests and rangelands, a background on wetland ecology and biology is needed to provide context for understanding the role of wetland soils in ecosystem services and their socioeconomic values.

\section{Wetland Soil Types}

In the United States, wetlands are defined on the basis of hydrology, soil properties, and composition of the vegetation. Specifically wetlands are lands that have a hydrologic regime where the site is either flooded permanently, periodically during the year, or the water table is at the soil surface during the growing season, the soils are hydric, and the vegetation is dominated by plants adapted for living in saturated soil conditions (US EPA 2015). Although the regulatory definition of wetlands by the US Army Corps of Engineers has regional variants, ${ }^{1}$ the requirement for hydric soils is consistent across the country. Hydric soils are defined as those "formed under conditions of saturation, flooding, or ponding long enough during the growing season to develop anaerobic conditions in the upper part" (Federal Register 13 July 1994). The USDA Natural Resources Conservation Service (hereafter, NRCS) maintains the list of hydric soils in the United States $^{2}$, along with characteristics of their physical and chemical properties, and soil surveys show the spatial distribution of hydric soils.

For consideration here, hydric soils may be categorized as either mineral or organic (Fig. 6.1). This distinction reflects conditions associated with the hydrogeomorphic setting and vegetation, which influences soil properties and processes. Accordingly, we consider mineral and organic soils separately. Hydric mineral soils occur in each of the soil taxonomic orders; in contrast, organic soils are represented by the Histosol order, which represents soils with a thick $(>40 \mathrm{~cm}$ ) accumulation of organic matter on top of mineral sediments or rock (Vasilas et al. 2016). Most of these soils within the Histosol order are formed under anoxic conditions (e.g., peat soils), but some soils form under aerated conditions, and hence they are not wetland soils and are distinctly recognized (e.g., suborder Folists) and not considered here. Histosols are also termed peatlands in the international literature, but the required thickness of the organic layer varies among countries. Mineral soils may also have a thin $(<40 \mathrm{~cm})$ accumulation of organic materials on the surface; when the organic layer is $15-40 \mathrm{~cm}$ thick, the soils are histic-mineral soils (Trettin and Jurgensen 2003).

\footnotetext{
${ }^{1}$ For regional supplements of the wetland definition, see https://www. usace.army.mil/Missions/Civil-Works/Regulatory-Program-andPermits/reg_supp/.

${ }^{2}$ For a list and description of hydric soils in the United States, see https://www.nrcs.usda.gov/wps/portal/nrcs/main/soils/use/hydric/.
} 

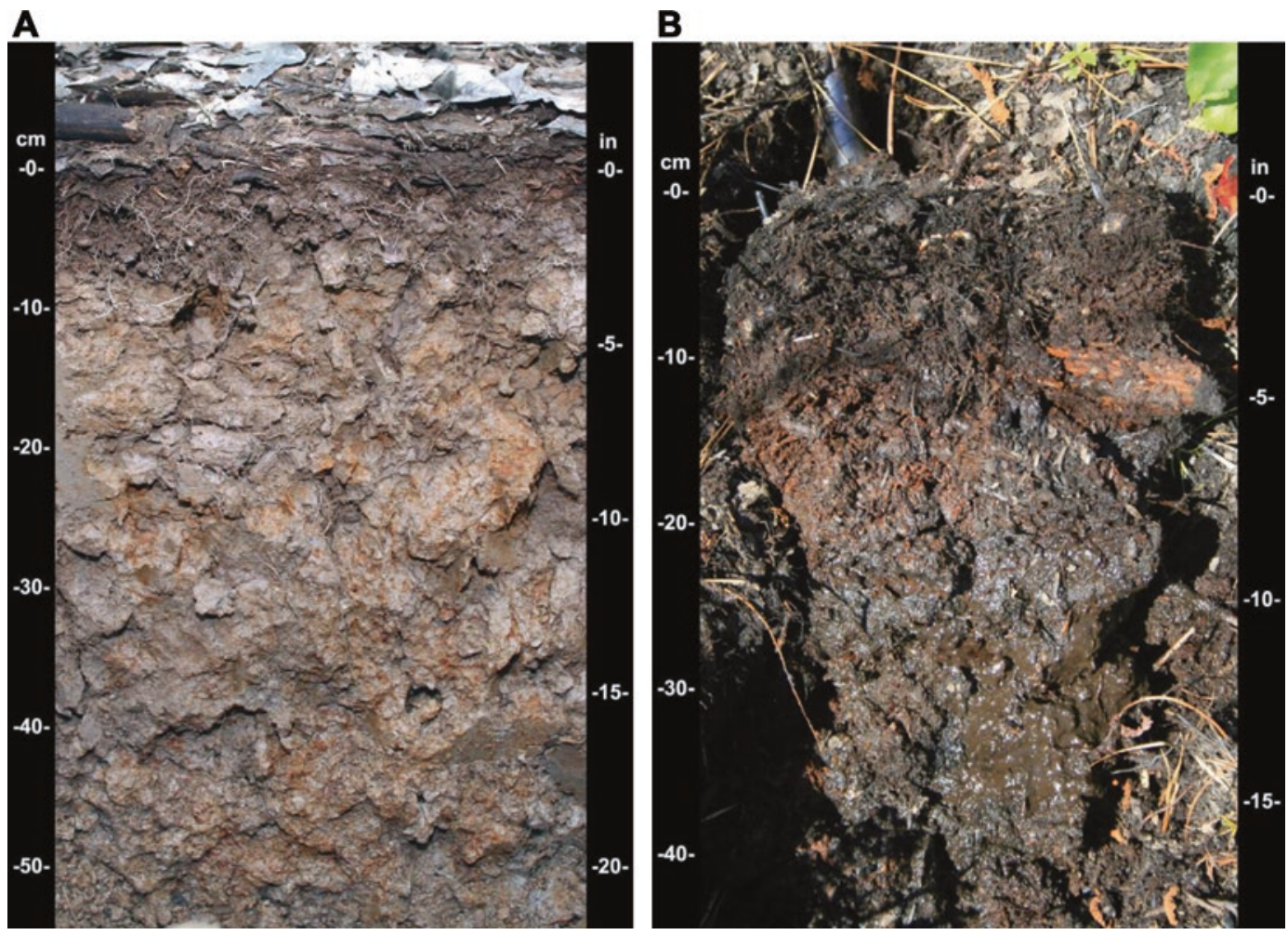

Fig. 6.1 Examples of hydric soils: (a) Mineral soils have a characteristic mottling; (b) organic soils typically lack mottling but have a thick accumulation of organic matter that is also indicative of anaerobic conditions. (Source: Vasilas et al. (2016))

\section{Tidal and Nontidal Wetlands}

The hydrologic regime of wetlands controls the anaerobic conditions in the soil, which are requisite for wetland biogeochemical functions. Nontidal wetlands are regulated by freshwater hydrology, with the source of the water being either precipitation or groundwater. These wetlands occur across a broad range of geomorphic surfaces from the tropics to the arctic. Correspondingly, the hydrologic regime is influenced by landscape position and climate, with the period of saturation varying from a few weeks to continuous. The National Wetlands Inventory classifies these nontidal freshwater wetlands into the Palustrine category, which does not convey information about the soil.

Tidal wetlands are those that have a hydrologic setting that is mediated by a combination of tidal waters, groundwater, and precipitation. Tidally influenced wetlands may occur in either marine or freshwater settings. The freshwater tidal zone occurs in low-gradient landscapes that have a large tidal amplitude, whereby the freshwater drainage is impeded by the oscillating tide. The salinity of marine-influenced wetlands varies from less than 0.2 to over 35 parts per thousand (ppt), depending on the position within the estuary or coastal zone. Wetland communities along the salinity gradient include a variety of plant communities (Fig. 6.2). Mangroves are the only forested wetland that occurs in saltwater tidal landscapes.

\section{Distribution of Wetlands}

There are approximately $420,462 \mathrm{~km}^{2}$ of freshwater wetlands and $23,347 \mathrm{~km}^{2}$ of tidal wetlands in the conterminous United States (Dahl 2011), with another $585,346 \mathrm{~km}^{2}$ of freshwater and tidal wetlands in Alaska (Clewley et al. 2015). Wetlands are widely distributed throughout the United States, but they are concentrated in Alaska and also in the Atlantic coastal plain, Mississippi Valley, the upper Great Lakes, and the Prairie Pothole Regions (Fig. 6.3). While a breakdown of the soil type has not been assessed for all wetlands, approximately $80 \%$ of the freshwater nontidal wetlands in the conterminous United States are mineral soil wetlands, with the balance being peatlands; $54 \%$ of freshwater wetlands are forested (Kolka et al. 2018). The mineral soil wetlands are widely distributed across the country, while organic soil wetlands or peatlands occur primarily in the upper Great Lakes region, the southeastern Atlantic coastal plain, and Alaska.

\section{Role of Soils in Wetland Ecosystem Functions}

An important consideration of terrestrial wetlands is that they receive inputs from uplands, and they discharge outputs to groundwater and adjacent waterways and uplands. Those inputs and outputs are predominantly conveyed through the soil by hydrologic forces. The soil water moves material 


\section{Cooper River Tidal Reach}

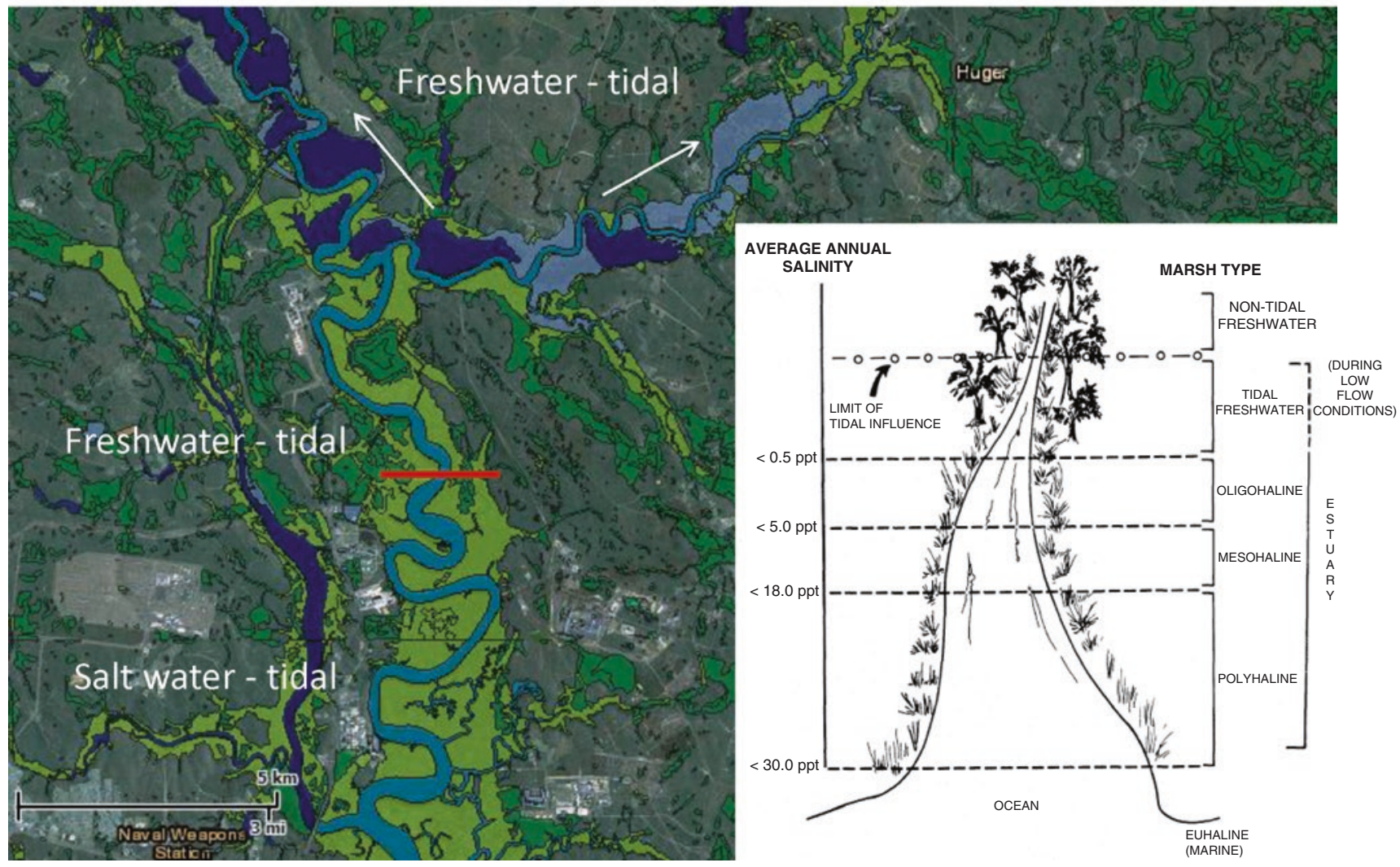

Fig. 6.2 Gradient in wetland communities from the tidal coast to the nontidal terrestrial zone along the East Branch Cooper River in South Carolina. (Source: Inset from Cowardin et al. (1979))

through the soil and also regulates soil aeration (Fig. 6.4). The continually shifting anoxic zone changes biogeochemical processes and rates, reflecting the highly dynamic and sensitive environment. Accordingly, hydrologic processes are inextricably linked to the soil biogeochemical processes. Resources are available that describe the details of wetland hydrology (Richardson et al. 2001; Verry 1997; Winter 1988; Winter and Woo 1990), hydric soil biogeochemistry (Vepraskas and Faulkner 2001), hydric soil biology (Craft 2001), hydric soil properties (Vepraskas 1996; Tiner 1999), wetland C cycle (Trettin and Jurgensen 2003), and wetland nutrient cycling (Lockaby and Walbridge 1998). Here we build on those fundamentals to synthesize soil processes across the range of basic soil materials (mineral-organic), water salinity (freshwatersaltwater), and hydrologic forcing (nontidal-tidal).

\section{Nontidal Wetlands}

\section{Mineral Soils}

Mineral soil wetlands (MSW) are found throughout the United States in various geomorphic settings, including river floodplains and deltas, glacially formed or aeolian-formed environments, sedimentary plains, and mountain ranges. Generally, MSW are characterized by restrictive drainage soils overlain by ponded water during a portion of the year. Substrates of MSW are characterized by intermittently to perpetually saturated or anoxic conditions, or both (Vepraskas and Craft 2016). Soils of MSW often have a mottled appearance (see Fig. 6.1) that is caused by the reduction, translocation, and oxidation of iron and manganese oxides. Compared to organic soil wetlands, the organic matter concentration, water holding capacity, porosity, and cation exchange capacity are generally lower in MSW. Conversely, MSW typically have greater soil bulk density, soil $\mathrm{pH}$, and nutrient availability (Mitsch and Gosselink 2015). Hydraulic conductivity can range from low to high, depending on soil properties. Primary water sources for MSW include precipitation and groundwater. Water losses are principally attributed to evapotranspiration, surface flow, and seepage or groundwater recharge (Hayashi et al. 2016; Winter 1989). Hence, the annual period of inundation, soil conditions, biotic communities (e.g., vegetation), and abiotic characteristics (e.g., water chemistry) of MSW can vary widely depending on climate, land use, hydrology, geomorphic setting, and vegetation (Euliss et al. 2004, 2014; Mushet et al. 2015). 


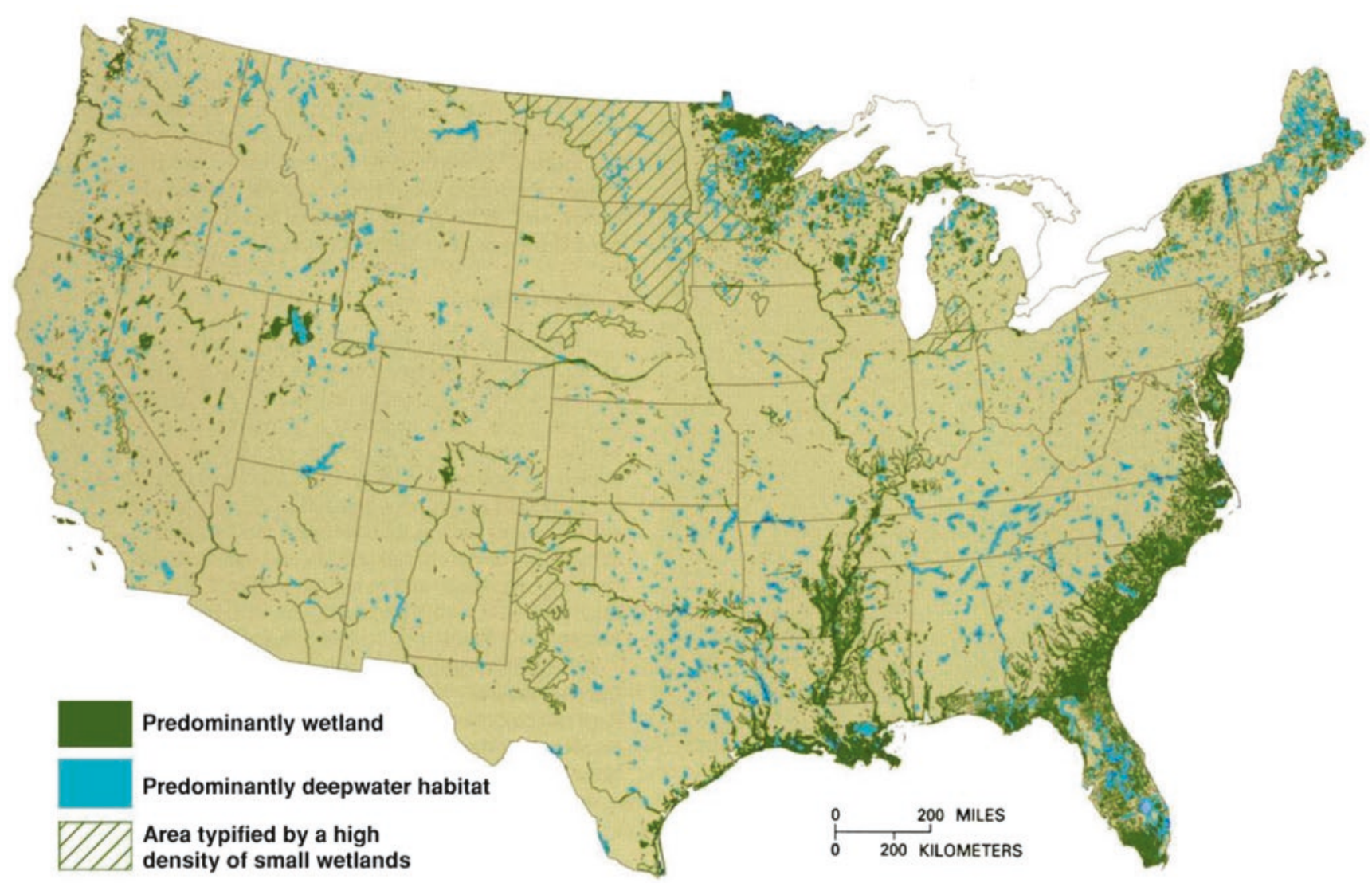

Fig. 6.3 Current distribution of wetlands in the conterminous United States. (Source: Dahl (2011))

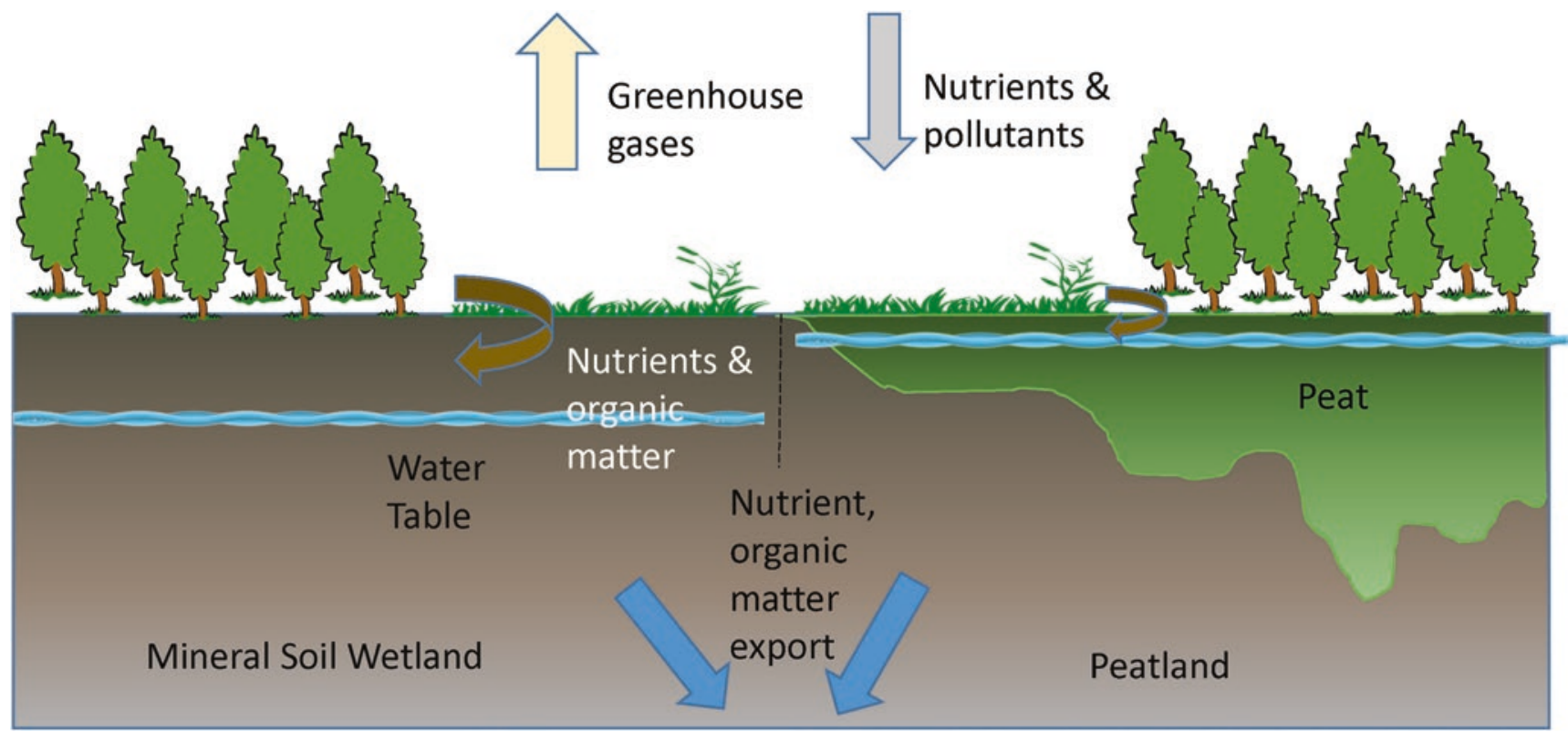

Fig. 6.4 Landscape cross section of uplands, wetlands, and water showing the water inputs, the water table, and the shifting anoxic zone in mineral and organic peat soils

Mineral soil wetlands often are distinguished by high primary and secondary productivity, which can be augmented through inputs of organic and mineral matter and nutrients from anthropogenic activities. The characteristic anoxic soil conditions of MSW result in relatively slow rates of decomposition of organic matter; thus, soils of 
MSW function as a long-term $\mathrm{C}$ sequestration or storage site (Euliss et al. 2006; Wickland et al. 2014). These anoxic soil conditions, when combined with abundant $\mathrm{C}$ stores, also provide conditions for microbial $\mathrm{CH}_{4}$ production (Bridgham et al. 2013; Mitsch et al. 2013). However, since saturated conditions can be short-lived for seasonally saturated wetlands, $\mathrm{CH}_{4}$ production can be extremely variable both temporally and spatially (Finocchiaro et al. 2014; Tangen et al. 2015). Moreover, some MSW, such as prairie potholes, can be characterized by high sulfate concentrations that can inhibit methanogenesis, even during times of extended saturated and anoxic conditions (Pennock et al. 2010). Many MSW, especially those embedded within agricultural landscapes, produce $\mathrm{N}_{2} \mathrm{O}$ through denitrification and nitrification processes that occur across the naturally occurring soil-moisture gradients (Bedard-Haughn et al. 2006; Tangen et al. 2015).

\section{Prairie Potholes}

The Prairie Pothole Region contains the largest concentration of MSW ecosystems in North America (see Box 6.1). It covers nearly $800,000 \mathrm{~km}^{2}$ of the north-central United States
(North Dakota, South Dakota, Minnesota, Iowa, and Montana) and south-central Canada (Manitoba, Alberta, and Saskatchewan) (Dahl 2014). The retreat of the Pleistocene glaciers (approximately 12,000 years ago) from the northern Great Plains left an undulating, hummocky landscape, draped by sediment and dotted with melting, stagnant ice blocks that eventually formed small depressions. The deposited glacial till had extremely low hydraulic conductivity. This allowed these depressions to remain saturated for extended periods, undergo oxidation-reduction processes (e.g., gleying), accumulate organic $\mathrm{C}$, and develop into functional wetlands (referred to as "potholes"). In total, there are an estimated 58 million potholes (Beeri and Phillips 2007) covering approximately $70,000 \mathrm{~km}^{2}$ of surface area (Dahl 2014; Euliss et al. 2006) within a matrix of croplands and grasslands. The majority of these wetlands are less than $0.01 \mathrm{~km}^{2}$ in area and have ponded water that is more than $2 \mathrm{~m}$ deep (Dahl 2014). Periods of inundation range from ephemeral to permanent, and salinities span a gradient from fresh to hypersaline (Euliss et al. 2004; Goldhaber et al. 2014; Niemuth et al. 2010; Winter and Rosenberry 1998) (Box Fig. 6.1).

Box 6.1

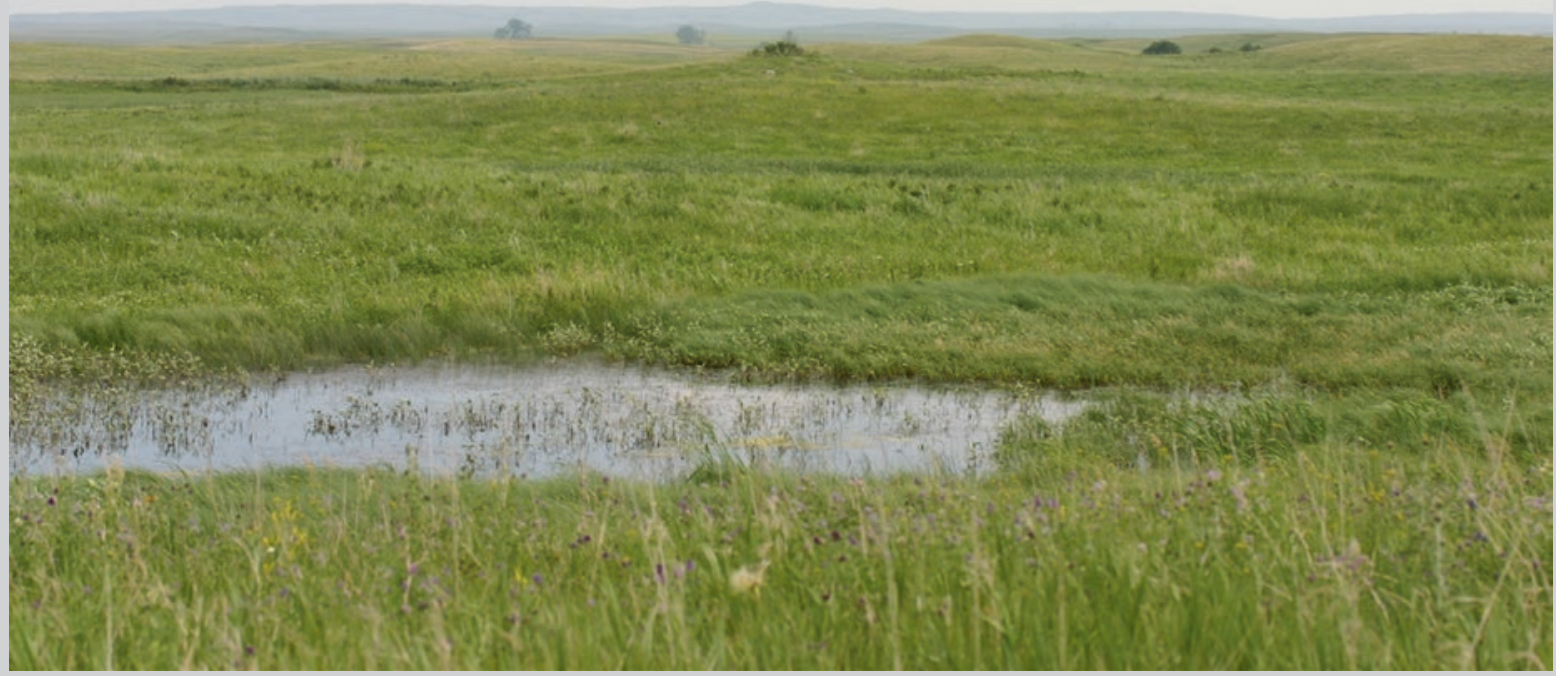

Box Fig. 6.1 A seasonal wetland in a native prairie grassland setting in the Prairie Pothole Region. The underlying glacial till in the region has extremely low hydraulic conductivity, allowing water to pond in small, shallow depressions referred to as "potholes." Pothole wetlands can function as groundwater discharge, recharge, or flow-through sites that vary in size, water chemistry, water per- manence, and biotic communities. These wetlands provide a range of ecosystem services, including breeding habitat for migratory waterfowl, pollinator and wildlife habitat, flood mitigation, filtration of pollutants, groundwater recharge, $\mathrm{C}$ sequestration, and nutrient retention. (Photo credit: Lawrence D. Igl, U.S. Geological Survey) 
Wetlands provide a range of ecosystem services, including breeding habitat for migratory waterfowl, pollinator and wildlife habitat, flood mitigation, filtration of pollutants, groundwater recharge, $\mathrm{C}$ sequestration, and nutrient retention. The gleyed soils of Prairie Pothole Region wetlands make them hotspots of biogeochemical activity due to the geologic history and critical zone processes in the region (Badiou et al. 2011; Bansal et al. 2016; Dalcin Martins et al. 2017; Goldhaber et al. 2014, 2016; Tangen et al. 2015).

Approximately 70 million years ago, an inland sea formed organic-rich marine shales that provided a source of pyrite in the glacial till underlying the Prairie Pothole Region. As groundwater slowly flows from topographically higher to lower wetlands (i.e., groundwater recharge to discharge, respectively), oxidation of pyrite and gypsum and subsequent dissolution of carbonates in the till result in an accumulation of ions such as sulfate $\left(\mathrm{SO}_{4}{ }^{2-}\right)$, bicarbonate $\left(\mathrm{HCO}_{3}{ }^{-}\right)$, calcium $\left(\mathrm{Ca}^{2+}\right)$, and magnesium $\left(\mathrm{Mg}^{2+}\right)$ in wetland soils and waters. Wetland chemistry is further controlled by evapotranspiration, mineral precipitation and dissolution, and biogeochemical processes. The concentrations of the various chemical constituents of Prairie Pothole Region wetlands have a strong bottom-up influence on the wetland plant and invertebrate communities (Euliss et al. 1999; Stewart and Kantrud 1972), which in turn influence fish, bird, and other wildlife populations (McLean et al. 2016a, b).

During the growing season, extensive stands of emergent macrophytes, combined with algal and submerged aquatic vegetation, contribute to high concentrations of dissolved organic carbon (DOC) and particulate organic $\mathrm{C}$ in standing water and sediment porewater of Prairie Pothole Region wetlands. These $\mathrm{C}$ inputs fuel some of the highest rates of $\mathrm{CH}_{4}$ flux (as high as $0.75 \mathrm{~g} \mathrm{CH}_{4} \mathrm{~m}^{-2}$ day $^{-1}$ ) and $\mathrm{SO}_{4}{ }^{2}$ reduction reported from freshwater wetlands (Dalcin Martins et al. 2017). Research suggests that wetlands with elevated $\mathrm{SO}_{4}{ }^{2}$ concentrations tend to have reduced $\mathrm{CH}_{4}$ emissions (Pennock et al. 2010), similar to marine tidal wetlands (Pennock et al. 2010; Poffenbarger et al. 2011). Denitrification and nitrification are also important processes in Prairie Pothole Region wetland soils. Wetlands that receive runoff from surrounding agricultural lands can produce large pulses of $\mathrm{N}_{2} \mathrm{O}$ emissions (Tangen et al. 2015). As C storage and sequestration sites and as sources of greenhouse gases (GHGs), Prairie Pothole Region wetlands have the potential to impact net GHG budgets of the United States (Badiou et al. 2011; Bridgham et al. 2006; Creed et al. 2013; Euliss et al. 2006; Tangen et al. 2015).

\section{Forested Mineral Soil Wetlands}

Forested mineral soil wetlands are found from the tropical coastal margin to the boreal zone. Lugo and others (1990) categorized these into four major forested wetland types within the United States.
Deep Water Swamps Deep water swamps are forested wetlands with standing water throughout all or most of the year (Conner and Buford 1998). Their distribution is primarily the coastal plain of the Southern United States, extending up the Mississippi River Valley into Southern Illinois. Vegetation is mainly baldcypress (Taxodium distichum), water tupelo (Nyssa aquatic), pond cypress (Taxodium ascendens), and swamp tupelo (Nyssa biflora) (Harms et al. 1998). While swamp soils are primarily histic, inclusions of Alfisols, Entisols, and Inceptisols occur on microsites where flooding is intermittent (Conner and Buford 1998). As an example, small mesic islands occur in the Great Dismal Swamp of Virginia, and forest communities on these sites resemble those of nearby uplands (Carter 1990). On a smaller scale, red maple (Acer rubrum) and black ash (Fraxinus nigra) swamps in the Northeastern United States may exhibit mineral soils with near-neutral $\mathrm{pH}$ and high levels of $\mathrm{Ca}$ and $\mathrm{Mg}$ (Ehrenfeld 2012).

Major Alluvial Floodplains Alluvial landforms are most often associated with morphologically younger soils (Entisols, Inceptisols). However, older soils (Ultisols, Alfisols, Mollisols) have been mapped in floodplains along the Atlantic Coast. Mineral soils occur in these floodplains on level and convex microrelief, while mineral soils approaching histic-mineral and organic soils dominate in concave positions (Anderson and Lockaby 2007).

Two types of forested floodplains, black-water and redwater, are recognized in the Eastern United States and reflect the source of the sediments carried by the river. Black-water rivers originate in the coastal plain and have a dark color due to the dissolved and suspended organic matter. Red-water rivers originate in the piedmont or mountains, with the color reflecting the suspended mineral sediments; sometimes these are called brown or even white water, depending on the color of the suspended clay and silt. Red-water rivers tend to exhibit relatively steep gradients that provide more energy to carry suspended sediment loads in comparison with the lower gradient black-water streams, which carry less sediment. Consequently, red-water systems often exhibit higher fertility than their black-water counterparts (Furch 1997; Schilling and Lockaby 2006). Although floodplains are generally more fertile than corresponding uplands, deficiencies of $\mathrm{N}$, phosphorus, and base cations are common and may restrict forest growth (Schilling and Lockaby 2006). These nutrient inadequacies are particularly common on blackwater sites. In spite of differences in nutrient content, Schilling and Lockaby (2006) were not able to discern major differences in net primary productivity (NPP) between two such floodplains in Georgia. The Mississippi Delta, the foremost alluvial floodplain in the United States, can be very 
productive and has exhibited some of the highest estimates of annual forest NPP in North America (Nelson et al. 1987).

Floodplains that occur in the arid Southwestern United States are distinct from those of humid regions. Streams associated with these systems may carry heavy sediment loads, and soil surfaces can be hydrophobic with sparse vegetation present (Stromberg et al. 2012). Soils vary from sandy loams to clay loams and may show little horizon development (Stromberg et al. 2012).

Minor Alluvial Floodplains Soils in the small alluvial floodplains are usually of local origin, in contrast to the soils of major floodplains (Hodges 1998). Soil texture varies with microrelief and distance from the stream. Typically, a natural levee or front occurs nearest the stream and is composed of sandy material. Behind that front, flats and lessor convex surfaces occur and may be clayey. Concave microrelief in the form of narrow sloughs may exhibit higher deposits of organic matter (Hodges 1998). In piedmont areas and near fall lines, minor floodplains are often buried in clay sediments deposited as a result of poor agricultural practices on uplands in the eighteenth, nineteenth, or early twentieth century (Trimble 1974). These sediment deposits can be very deep ( $>2 \mathrm{~m}$ ) and usually consist of clays.

Wet Flatwoods In the Atlantic coastal plain, flatwoods sites are predominantly occupied by loblolly (Pinus taeda) and slash pine (Pinus elliottii), with inclusions of pond pine (Pinus serotina) on wetter areas. However, on slightly higher elevations and if fire has been excluded, hardwoods may dominate with swamp laurel (Quercus laurifolia), water oak (Quercus nigra), and willow oak (Quercus phellos), along with red maple, green ash (Fraxinus pennsylvanica), and American elm (Ulmus americana) (Harms et al. 1998). Soil diversity is generally high, and Aquods are often present with wet Alfisols and Ultisols (Harms et al. 1998). Many of these sites exhibit pronounced phosphorus deficiency, and productivity is often increased dramatically by the addition of phosphorus fertilizer (Harms et al. 1998).

\section{Organic Soils}

Organic soils are the distinguishing characteristic of peatlands as a wetland class. Peatlands accumulate significant amounts of soil organic matter, or peat, when plant production exceeds decomposition over time (Kolka et al. 2011a; Sahrawat 2004). In the United States, nonfrozen peatlands occupy approximately $163,000 \mathrm{~km}^{2}$, with Alaska contributing about $48 \%$ of that area. Although nonfrozen peatlands only represent about $23 \%$ of the total nontidal wetland area in the United States, they store about $46 \%\left(14.2 \times 10^{12} \mathrm{~kg}\right.$, or 14.2 petagrams $\left.[\mathrm{Pg}]\right)$ of wetland C, with approximately $41 \%$ in Alaska (Kolka et al.
2018). Peatlands in the United States are also important sources of $\mathrm{CH}_{4}$ to the atmosphere, contributing $3.2 \times 10^{9} \mathrm{~kg}$ or 3.2 teragrams (Tg) $\mathrm{C} \mathrm{year}^{-1}$ (Kolka et al. 2018). Peatland accumulation rates range from 0.18 to $7.8 \mathrm{~mm}^{\text {year }}{ }^{-1}$, with lower rates associated with higher latitudes (Kolka et al. 2011a, b). In both forested and nonforested peatlands, $\mathrm{C}$ is mainly sequestered in the organic soils, with much less sequestered aboveground in trees, shrubs, and sedges.

Generally, there are two types of peatlands: fens, which are those that are connected to the regional groundwater, and bogs, which have a perched water table and are not connected to the regional groundwater. In both hydrologic conditions, forested and nonforested peatlands exist. Those that are connected to the regional groundwater tend to be more nutrient rich, have a higher $\mathrm{pH}$, and support more diverse plant communities.

\section{Nonforested Peatlands}

Nonforested peatlands include wetland types such as marshes and some fens and open bogs. Nonforested peatlands are usually a result of high water tables that are consistently near the surface. These high water tables are generally a function of being connected to the regional groundwater system leading to a fen ecosystem (Winter and Woo 1990), but they can also have high perched water tables, as in the case of open bogs. Because of the connection to regional groundwater that tends to be higher in nutrients, cations, and anions, these plant communities tend to be more productive and diverse than those that are only fed by precipitation (see discussion in Forested Peatlands section). Because many nonforested peatlands are connected to the regional water table, the large supply of water makes them less susceptible than forested peatlands to changes in precipitation regimes. This connection to groundwater can also cause $\mathrm{pH}$, exchangeable cations, $\mathrm{N}$, and $\mathrm{P}$ to vary widely. Open bogs are generally at the lower $\mathrm{pH}$ and nutrient end of the gradient, with $\mathrm{pH}$, cations, and other nutrients ranging from intermediate to high in fens. Under normal conditions, fens and bogs are net sinks for $\mathrm{CO}_{2}$, but they can be sources of $\mathrm{CH}_{4}$ (Turetsky et al. 2014). Ecosystem storage of $\mathrm{C}$ ranges from approximately 400 to $1500 \mathrm{Mg} \mathrm{C} \mathrm{ha-1,} \mathrm{while} \mathrm{CH}_{4}$ fluxes range from 0.02 to 0.07 Mg C ha' year $^{-1}$ (Kolka et al. 2018).

\section{Forested Peatlands}

Forested peatlands include wetland types such as forested bogs, forested fens, bottomland hardwood swamps, pocosins, and Carolina bays. Forested peatlands are usually a result of variable water tables that typically draw down at times, especially during the growing season. Peatlands that have the most variable water tables are generally those that are perched and fed mainly by precipitation. Water table drawdown allows an aerobic soil/root system that enhances growth of the plant community and allows shrubs and trees 
to grow. As in nonforested peatlands, forested peatlands that are only fed by precipitation (e.g., forested bogs) tend to be have lower concentrations of nutrients, cations, anions, and $\mathrm{pH}$ than those fed primarily by groundwater (forested fens) or surface water (swamps). Forested peatlands associated with a variable water table fed only by precipitation are more susceptible to long-term changes in precipitation regimes, especially droughts (Zoltai et al. 1998). Ecosystem storage of $\mathrm{C}$ ranges from approximately 410 to $1820 \mathrm{Mg} \mathrm{C} \mathrm{ha}^{-1}$, while $\mathrm{CH}_{4}$ fluxes range from 0.02 to $0.08 \mathrm{Mg} \mathrm{C} \mathrm{ha}^{-1}$ year $^{-1}$ (Kolka et al. 2018).

\section{Tidal Wetlands}

Tidal wetlands occupy the intertidal margins of shorelines, extending from shallow coastal bays and estuaries into reaches of coastal rivers. They share tidal hydrology arising from ocean tides that propagate inland into estuaries, bays, and rivers and therefore vary widely in salinity from fullstrength seawater to brackish to freshwater. Tidal marshes are dominated by herbaceous plant species, while tidal forests are dominated by mangroves in the marine setting and bottomland hardwood swamp species in the freshwater tidal areas. Shrub-dominated tidal wetlands are known as shrubscrub ecosystems. Tidal wetlands occur on both mineral and organic soils; soil type is a characteristic that affects the physical stability of the system against accelerated sea level rise and biogeochemical processes such as suppression of $\mathrm{CH}_{4}$ emissions by iron (Fe (III)) respiration (Neubauer et al. 2005).

Tidal wetlands are zones of intense biogeochemical activity within the coastal plain landscape due to regular tidal flooding and direct connectivity to rivers and estuaries. They are dynamic environments where high rates of plant production, microbial activity, and hydrologic exchange influence adjacent aquatic ecosystems, groundwater, and the atmosphere (Megonigal and Neubauer 2009). Tidally driven hydrology generally produces open element cycles compared to nontidal wetlands, a concept embodied in the Outwelling hypothesis, which links tidal wetland and aquatic biogeochemical cycles (Odum et al. 1995). Tidal wetlands are an important source of C to estuaries (Nixon 1980), which supports microbial metabolism and nutrient cycling and regulates ultraviolet light penetration of the water column.

Element cycles in freshwater, brackish, and saline tidal wetlands are constrained by many of the same factors. Flooding frequency is the most important factor regulating primary production in tidal marshes; peak production of herbaceous plants at an intermediate flooding frequency varies by species. Production is limited by N, P, or both $\mathrm{N}$ and $\mathrm{P}$, depending on the geomorphic setting and anthropogenic nutrient loading. Coastal eutrophication tends to increase plant growth, decrease root-shoot ratio, and trigger changes in microbial metabolism and decomposition. The net effect of these responses on $\mathrm{C}$ sequestration, elevation gain, and ecosystem stability can be positive or negative for reasons that remain unclear (Megonigal and Neubauer 2009).

Tidal wetlands are referred to as "blue carbon ecosystems" because they hold large stocks of soil and plant $\mathrm{C}$ and support rapid rates of $\mathrm{C}$ sequestration (Chmura et al. 2003; McLeod et al. 2011). Marshes, mangroves, and seagrass meadows account for about half of the total marine soil $\mathrm{C}$ budget (Duarte et al. 2005) and bury an amount of C equivalent to that stored by terrestrial forests, despite occupying just $2.5 \%$ of all land area (McLeod et al. 2011). These high rates of $\mathrm{C}$ sequestration are attributed to interactions among three primary factors: rapid plant production, slow decomposition, and sea level rise (Kirwan and Megonigal 2013). As rates of sea level rise accelerate, coastal wetlands have the potential to sequester soil $\mathrm{C}$ at increasingly rapid rates as long as plants survive flooding and contribute to soil building. Compared to upland soils, the sequestration potential of tidal wetland soils is extremely high because rising sea level increases the potential soil volume over time. Coastal wetlands have only recently been recognized as important $\mathrm{C}$ sinks, and therefore, their response to global change is largely unexplored. The future stability of these systems is uncertain because global change drivers such as temperature and elevated $\mathrm{CO}_{2}$ perturb the complex biotic and abiotic feedbacks that drive high rates of soil $\mathrm{C}$ sequestration (Kirwan and Mudd 2012).

Tidal wetlands have the capacity to gain elevation by a combination of sediment trapping and in situ addition of organic $\mathrm{C}$, the major processes driving soil development and $\mathrm{C}$ stocks. Accordingly, the difference in elevation between sea level rise and sediment accretion reflects the net change in submergence depth. The relative importance of mineral versus organic material to elevation gain depends on a variety of hydrogeomorphic variables such as tidal range, soil surface elevation, and sediment supply and ecological variables such as plant community composition, net primary production, and the relative contributions of aerobic versus anaerobic microbial respiration. Organic matter accounts for up to $80 \%$ of soil mass in tidal wetlands, occupying about twice the volume of mineral matter on a mass basis and contributing at least twice as much to accretion as an equal mass of minerals (Neubauer 2008; Turner et al. 2000). Tidal wetlands with organic soils are typically perched high in the tidal frame, which decreases their vulnerability to rapid sea level rise; however, they are also more vulnerable to elevation loss caused by plant stress due to increased flooding or salinity. 


\section{Tidal Freshwater Wetlands}

Tidal forcing by oceans can extend upstream into coastal rivers, creating a unique combination of freshwater with floodebb tidal cycles. Tidal freshwater wetlands (TFWs) are common on all US coasts where nontidal rivers and tidal estuaries meet. Elevation transitions mark changes in plant community composition, with low and intermediate elevations dominated by herbaceous species (e.g., marshes) and high elevations dominated by trees (e.g., tidal freshwater swamps). The primary production of trees in TFW is limited by frequent flooding, while herbaceous production is comparable to brackish and salt marshes.

TFWs have several unique features. TFW hydrology lacks the strong seasonal variability of nontidal freshwater due to tidal forcing, which means that hydrologic exchanges and greenhouse gas emissions are relatively stable. The lack of salinity leads to plant communities that are far more diverse than saline tidal wetlands. One consequence of low salinity is a limited supply of sulfate, a terminal electron acceptor that effectively suppresses production of $\mathrm{CH}_{4}$ emissions. As a result, TFWs support higher $\mathrm{CH}_{4}$ emissions than saline wetlands (Bartlett et al. 1987; Poffenbarger et al. 2011). Dissolved inorganic $C$ and alkalinity exported from TFWs to rivers can potentially have a relatively large effect on river carbonate chemistry because freshwaters are poorly buffered compared to saline estuarine water.

\section{Tidal Marine Wetlands}

The combination of tidal hydrology and high salinity gives rise to wetlands characterized by low species diversity and microbial respiration dominated by sulfate reduction. At salinity levels more than 0.5 practical salinity units (psu), all tree species and most herbaceous species in TFWs are replaced by a limited number of plant species with specialized adaptations to salinity stress. Temperature is an important factor in the distribution and function of tidal marine ecosystems because it determines whether mangrove species are present. Mangroves are restricted to tropical and subtropical climates but can occupy intertidal areas regardless of salinity. Tidal freshwater swamps and tidal freshwater mangroves are distinctions of plant species composition and latitude and are not necessarily meaningful for understanding differences in element cycling.

Salinity affects microbial processes that regulate C cycling and greenhouse gas emissions. Sulfate contributes about $8 \%$ of the salts in seawater, and it is a dominant substrate for microbial respiration in marine tidal wetland soils. Sulfate-reducing bacteria outcompete microorganisms that produce $\mathrm{CH}_{4}$, effectively suppressing $\mathrm{CH}_{4}$ emissions from tidal wetlands in proportion to sulfate availability. The relationship between salinity and $\mathrm{CH}_{4}$ emissions is used to predict the point at which the radiative cooling effect of $\mathrm{CO}_{2}$ capture through soil $\mathrm{C}$ sequestration is balanced by the heat- ing effect of $\mathrm{CH}_{4}$ emissions in tidal wetlands of varying salinity. Above 18 psu, tidal wetlands are net sinks of $\mathrm{CO}_{2}$ by one conservative estimate (Poffenbarger et al. 2011), but this remains an area of significant uncertainty.

\section{Sustainability of Wetland Functions and Ecosystem Services with Changing Conditions}

As previously summarized, wetlands and associated soil processes are sensitive to their inherent setting and associated hydrologic, biotic, and abiotic conditions. Here we summarize the sensitivities of wetlands to changing conditions resulting from both natural and anthropogenic causes.

\section{Long-Term Climate Variability}

Projected increases in temperature and changes in the frequency and intensity of precipitation are likely to impact wetland soil function, primarily as a result of changes in the water regime. Over the coming decades, average annual temperatures are expected to warm by $1.4{ }^{\circ} \mathrm{C}$, and even more in northern latitudes (Vose et al. 2017). Higher temperatures can alter hydrology by increasing evapotranspiration, melting permafrost, and changing the amount and timing of runoff and groundwater recharge from snowmelt and glaciers. Wetland hydrology may be further impacted by precipitation that contributes to hydrologic inputs, including a projected decrease in winter and spring precipitation in the Southwest and an increase in precipitation in the northern United States and Alaska (Easterling et al. 2017). Heavy precipitation is likely to increase by as much as $10-20 \%$ by the end of the century over the entire United States, with the potential to contribute to extreme flooding in some wetlands (Easterling et al. 2017). Warming is expected to increase drought conditions and alter the frequency and severity of wildfires, particularly in the western United States and Alaska, where peatlands are vulnerable to new fire regimes (Young et al. 2016).

\section{Long-Term Shifts in Temperature and Precipitation}

\section{Vegetation Response}

Shifts in temperature, precipitation, and the combination of both will alter species composition and diversity and, in some instances, ecosystem function of vegetated wetlands. In northern alpine wetlands, an increase in air temperature is expected to result in faster-growing species from lower latitudes outcompeting and replacing slower-growing species (Burkett and Kusler 2000). In salt marshes, warming has 
been shown to change the native plant assemblage (Gedan and Bertness 2009; McKee et al. 2012). Warming will also allow tropical mangrove species to expand their northern range in the United States. A decrease in the number of freezing events has decreased and allowed the black mangrove (Avicennia germinans) to expand into salt marsh ecosystems (Saintilan et al. 2014; Simpson et al. 2017), thus increasing mangrove area by more than $70 \%$ along the Texas coastline (Armitage et al. 2015). A decrease in precipitation will shift freshwater wetland plant communities to communities that include plant species that are more tolerant of drier conditions, or even replace them entirely with upland species (Burkett and Kusler 2000; Johnson and Poiani 2016; Mortsch 1998).

Changes in temperature and precipitation will also affect wetland biomass production. Marsh productivity increased by $10-40 \%$ as temperatures naturally increased by $4{ }^{\circ} \mathrm{C}$ along a latitudinal gradient (Kirwan et al. 2009). Experimental warming increased aboveground growth of two salt marsh plants, saltmeadow cordgrass (Spartina patens) and smooth cordgrass (S. alterniflora), by 14-45\% (Gedan et al. 2011). This increase in productivity will result in increased litter production, thereby affecting organic matter turnover, greenhouse gas emissions, and soil organic matter (Ellison 2000). However, once temperatures go beyond plant thresholds (e.g., $-40{ }^{\circ} \mathrm{C}$ for mangroves), production will decrease (Clough et al. 1982; Mortsch 1998). Decreased precipitation can alleviate stress from waterlogged conditions in some marshes (Charles and Dukes 2009), but when combined with warmer temperatures, it will also lower water tables, increase soil salinity, and expose sediments to aerobic conditions that increase organic matter decomposition (Burkett and Kusler 2000; Clair et al. 1995; Morrissey et al. 2014; Mortsch 1998). These conditions may decrease plant productivity (Field 1995; Day et al. 2008) as well as increase aerobic decomposition of wetland soils, and thus, $\mathrm{CO}_{2}$ fluxes to the atmosphere (Field 1995; Moor et al. 2015). In mangroves and salt marsh systems that need to maintain their elevation relative to sea level, increased decomposition of peat has impacted their ability to keep up with sea level (Bridgham et al. 1995; Burkett and Kusler 2000; Rogers et al. 2014; Woo 1992). Alternatively, increased precipitation increases plant growth, seedling survival, and seed germination by reducing salinity and osmotic stress of plants and trees (Clough et al. 1982; Ellison 2000; Field 1995; Noe and Zedler 2001). Increased precipitation will also increase peat and sediment accumulation through increased delivery of sediments from flooding, peat production through root growth, and organic matter accumulation from litter inputs (Rogers et al. 2014; Sanders et al. 2016; Scavia et al. 2002). This increased peat and sediment accumulation has allowed mangroves and salt marshes to keep up with sea level (Eslami-Andargoli et al. 2009; Rogers et al. 2014; Snedaker 1995).
Changes in community composition and production may affect functionality of wetland soils. Positive impacts include increased $\mathrm{C}$ stocks and $\mathrm{C}$ accumulation rates that can potentially offset climate change impacts (Donato et al. 2012; MacKenzie et al. 2016). For example, mangrove migration into salt marshes has significantly increased aboveground and belowground $\mathrm{C}$ stocks by $2.3 \mathrm{Mg} \mathrm{C}^{-1}$ year $^{-1}$ (Kelleway et al. 2016; Simpson et al. 2017). Shifts in plant communities in fens would result in greater root depths and higher $\mathrm{C}$ storage. Alternatively, this could result in lower $\mathrm{C}$ storage if roots increase peat/soil oxygenation that fuels organic matter decomposition (Moor et al. 2015). Shifts in community composition can also impact accretion and sedimentation rates of wetlands. Increased sediment loads and belowground $\mathrm{C}$ accumulation are two mechanisms that help wetlands maintain their position relative to sea level (Krauss et al. 2014). Thus, decreased productivity and decreased litter and root inputs will negatively impact the ability of wetlands to maintain their position relative to sea level. Shifts in wetland plant communities can also decrease nutrient soil storage or increase peat decomposition.

\section{Altered Hydrology}

Changes in long-term precipitation and temperature regimes are expected to alter wetland hydrology, impacting soil function and ecosystem feedbacks. Differences in wetland landscape position and regional variability in temperature and precipitation suggest that responses are likely to vary widely. In some cases, the hydrologic conditions that define wetlands may cease to exist, and wetlands will transition to uplands or open water systems.

Increased evaporative losses, particularly when coupled with decreases in precipitation, may lead to declines in the water table and less frequent flooding in riparian wetlands. Wetlands in arid to mesic environments may be particularly vulnerable (Johnson et al. 2005; Springer et al. 2015). In prairie pothole wetlands, climate simulations indicate that a $3{ }^{\circ} \mathrm{C}$ increase in temperature combined with a $20 \%$ decrease in precipitation would increase the amount of emergent vegetation, shifting the community to a dry marsh with significantly less open water available for waterfowl (Johnson et al. 2005).

In peatlands, droughts have been found to increase soil microbial activity and C loss (Griffis et al. 2000; Laiho 2006). Drying can increase the oxidation of peat, which enhances microbial growth and promotes enzymatic activity that reduces phenolic compounds, further contributing to microbial decomposition and growth (Fenner and Freeman 2011). Warmer temperatures increase enzymatic activation rates, but responses may vary with the complexity of the substrate (Davidson and Janssens 2006). Warmer, drier peatland soils may also promote increased recruitment and growth of shrubs (Waddington et al. 2015), which in turn may increase transpiration interception losses. 
Greater amounts of precipitation may increase the period and depth of wetland flooding, if not offset by evaporative losses. Depressional wetlands may be particularly susceptible to increased precipitation because of their topography and drainage (Johnson et al. 2004; Mitsch et al. 2013). Longterm changes in extreme flooding in riverine wetlands and direct links to climate change are less clear, as changes in streamflow can be affected by land use, dams, and other factors (Walsh et al. 2014).

Increased flooding may also result in decreased $\mathrm{CO}_{2}$ and increased $\mathrm{CH}_{4}$ and $\mathrm{N}_{2} \mathrm{O}$ emissions, as microbial respiration shifts from aerobic to anaerobic soil conditions ( $\mathrm{Yu}$ et al. 2008). Increases in $\mathrm{CH}_{4}$ and $\mathrm{N}_{2} \mathrm{O}$ emissions may be of particular concern because these trace gases have greater global warming potentials than $\mathrm{CO}_{2}$. However, much is still unknown about the release of $\mathrm{CH}_{4}$ from wetland soils, including the capacity for $\mathrm{CH}_{4}$ oxidation as it diffuses through the soil column (Segarra et al. 2015).

\section{Thawing of Permafrost Wetlands}

The primary threat to continuous permafrost, discontinuous permafrost, and sporadic and isolated zones in wetland soils in northern latitudes is long-term climatic warming that leads to soil thawing. Permafrost has a seasonal cycle where the near-surface ice in the soil melts during warmer seasons. The active layer defines the extent of this thaw zone and varies depending on aspect, topography, and soil conditions. The depth of this thaw also governs the physical stability of the ground. Extensive thawing of frozen soils can destabilize the landscape, resulting in changes to the landscape structure that affect the fate of the soil system when it refreezes and the active layer is once again frozen. Extensive thawing can result in features such as patterned ground and ice-wedge polygons that can change so dramatically that structures and vegetation communities are altered.

A major concern of the increased soil thaw is the exposure of $\mathrm{C}$ pools to decomposition. Overall, the northern latitude soils of the arctic and boreal regions contain $2050 \mathrm{Pg} \mathrm{C}$ (to a depth of $3 \mathrm{~m}$ ) (Schuur et al. 2015). Thawing and exposure of previously frozen soil horizons can release $\mathrm{C}$ either as a gas through respiration or secondary products as dissolved organic carbon (DOC). The enhanced losses of these $\mathrm{C}$ pools from the soil have both global implications for the balance of greenhouse gases in the atmosphere and terrestrial realms, as well as for the associated aquatic communities that face increased amounts of dissolved organic matter mobilized from the soil pool.

In thawed permafrost soils, the presence of melt water can maintain anaerobic conditions that deter the rapid oxidation of organic matter (Shurr et al. 2018). However, the potential for $\mathrm{CH}_{4}$ flux increases, leading to enhanced emissions of both $\mathrm{CH}_{4}$ and $\mathrm{CO}_{2}$ from the active layer of permafrost soils. Saturated soils can also enhance the movement of DOC from the soil. Subsidence of soil surface horizons is common upon melt. The lowering of the surface coincides with a rise in the water table, so anaerobic conditions are maintained and gaseous losses are mitigated. However, the potential drainage of soil water due to collapse features can expand these features, which is especially threatening to physical structures, such as roads and buildings.

\section{Sea Level Rise}

Many coastal wetlands will face increased inundation, saltwater intrusion, and salinity stress as sea level rise approaches 1-4 m by 2100 (Mendelssohn and Morris 2002). Many of these wetlands will be subject to warmer ocean temperatures and increased exposure to hurricanes and associated storm surges. These impacts may be compounded by shifts in freshwater, sediment, and nutrient inputs to coastal wetlands; northward migration of species such as mangroves; and changes in the productivity of wetland plants (Megonigal et al. 2016).

Flooding frequency is the single most important factor that governs tidal wetland ecology and biogeochemistry, and it is currently changing at an accelerated pace due to a combination of sea level rise and land subsidence. Sea level rose more than $2 \mathrm{~m}$ over the last 4000 years, and it is forecast to rise by the same amount over the next 200 years. Simultaneously, land is subsiding at variable rates that are increasing in some locations due to factors such as groundwater withdrawal. Considerable uncertainty remains as to the capacity of tidal wetlands to keep pace with relative sea level rise through a combination of elevation gain and horizontal migration into uplands. However, it is well established that the most vulnerable systems are those with small tidal ranges and low sediment supplies, conditions that are typical of large areas of tidal marine wetlands, such as those in Chesapeake Bay and the Mississippi River delta. Tidal freshwater wetlands may be less vulnerable than some tidal marine wetlands because they typically occur near upstream sediment sources.

Sea level rise is changing the boundary between tidal freshwater wetlands and tidal marine wetlands, with uncertain consequences for $\mathrm{C}$ stocks and element cycling. Organic accretion rates tend to be higher in TFWs than tidal marine wetlands (Craft 2007), suggesting that increasing salinity intrusion may cause soil $\mathrm{C}$ sequestration to decline. However, studies on the direct effects of sulfate on soil organic matter decomposition rates have reported both accelerated rates and no change in rates (D'Angelo and Reddy 1999; Weston et al. 2006, 2011) but provide little mechanistic insights to explain these differences (Sutton-Grier and Megonigal 2011). There are also perplexing observations that are not adequately explained by our present understanding of anaerobic decomposition, such as reports that increased inundation caused faster rates of soil organic matter decomposition (Kirwan 
et al. 2013; Mueller et al. 2016) and that increased salinity stimulated $\mathrm{CH}_{4}$ emissions (Weston et al. 2011).

Salinity changes can affect a number of nutrient cycling processes, including $\mathrm{P}$ adsorption, denitrification, and nitrification (e.g., Caraco et al. 1989; Howarth 1988). The intrusion of saltwater and associated $\mathrm{SO}_{4}{ }^{2-}$ can lead to the breakdown of the "iron curtain" described by Chambers and Odum (1990), which releases sediment-bound P (Caraco et al. 1989). Elevated salinity can also lead to decreased sorption of $\mathrm{NH}_{4}{ }^{+}$to soil particles, and increased $\mathrm{NH}_{4}$ concentrations may suppress $\mathrm{N}_{2}$ fixation (e.g., Howarth 1988). The physiological effects of salinity on nitrifying and denitrifying microbes reduce the activity of these organisms (Furumai et al. 1988; MacFarlane and Hebert 1984; Stehr et al. 1995). Much of the research on the effects of rising salinity on soil and sediment biogeochemistry has focused on transient effects. Over longer time periods, salt-sensitive plants, animals, and microbes will likely be replaced by salt-tolerant species (e.g., Magalhães et al. 2005). Relatively little is known from direct manipulations of salinity about the direction of these longer-term effects.

Sea level rise will increase the landward progression of tidal freshwater wetlands. The resulting conversion of nontidal to tidal wetlands will result in significantly increased periods of soil anoxia, which would be expected to cause corresponding changes in the $\mathrm{C}$ and nutrient cycles.

\section{Extreme Events}

\section{Fire}

Increased temperatures and evapotranspiration, when not offset by precipitation, are expected to lead to drier fuels and lower water tables in many northern peatlands (Flannigan et al. 2009), which in turn are likely to increase wildfire frequency, particularly in summers with extreme heat and low moisture availability (Young et al. 2016). This response is evident in Alaska, where fire frequency, duration, and intensity have increased over the past several decades (Flannigan et al. 2009; Kasischke and Turetsky 2006; Partain et al. 2016; Sanford et al. 2015).

Increased wildfire activity in peatlands will reduce soil $\mathrm{C}$ stocks, releasing $\mathrm{CO}_{2}$ and other greenhouse gases into the atmosphere (McGuire et al. 2009). Peatland fires in western Canada alone are estimated to emit up to $6 \mathrm{Tg} \mathrm{C}$ year $^{-1}$ (Turetsky et al. 2004). In black spruce (Picea mariana) stands of Alaska, decadal fire emissions exceeded ecosystem uptake by as much as $86 \pm 16 \mathrm{Tg} \mathrm{C}$ (Turetsky et al. 2011) The increase in severity of fires has been shown to increase the depth of organic soil burning, which can result in particularly high C emissions (Turetsky et al. 2011), and their smoldering may contribute to atmospheric pollution (Flannigan et al. 2009). Smoke may also increase albedo, which may help offset radiative forcing from the fire's greenhouse gases (Lyon et al. 2008; Randerson et al. 2006).

\section{Floods Resulting from Increased Incidence of Severe Storms}

Extreme precipitation events are becoming more severe and frequent (Min et al. 2011) in many parts of the United States (Groisman et al. 2012; Kunkel et al. 1999) as well as globally (Groisman et al. 2005), with consequences to structures and infrastructure, including houses, dams, roads, sewer and stormwater drainage, and drinking water systems (Gariano and Guzzetti 2016; Mamo 2015). While the role of wetlands within the watershed on storm runoff is recognized (Johnston et al. 1990), extreme events suggest the need to consider the role of wetlands especially in urbanizing landscapes. The interactions of road and stormwater conveyance infrastructure and other water management systems with extreme precipitation events are relatively unknown, presenting risks to downslope resources. While flooding is the obvious risk (Amatya et al. 2016), storms may significantly increase the sediment transported by the waterways as well (Shelby et al. 2005).

\section{Atmospheric Effects}

Humans have altered the chemistry of the atmosphere via a number of processes, including fossil fuel combustion, land use change, volatilization from agricultural activities, incineration, and other industrial processes (Monks et al. 2009). These atmospheric changes can affect wetland soils either via direct positive and negative effects on plants (e.g., $\mathrm{CO}_{2}$, nitrogen and sulfur oxides, ozone) or via wet and dry deposition onto soils (e.g., reduced and oxidized N, sulfur oxides, and $\mathrm{Hg}$ ). Wetland-specific soil impacts often derive from the interaction of these pollutants with anoxic sediments.

\section{Elevated $\mathrm{CO}_{2}$}

In addition to its effect on climate, increasing $\mathrm{CO}_{2}$ can have a direct effect on photosynthesis because $\mathrm{CO}_{2}$ is one of the key substrates for this process. Numerous upland studies have shown that elevated $\mathrm{CO}_{2}$ can increase plant photosynthetic rates and subsequently increase productivity, if no other conditions, such as $\mathrm{N}$, other nutrients, or light, are limiting (Johnson 2006). Without limitations, elevated $\mathrm{CO}_{2}$ leads to higher plant production, longer growing seasons, and higher leaf area (Hyvönen et al. 2007), as well as lower stomatal conductance and transpiration and higher water use 
and light use efficiency (Drake et al. 1996). Those principals are presumed for wetlands, which have not received the degree of study compared to uplands, and they are supported by several studies indicating similar responses for wetland plant communities. For example, in sedge wetlands, photosynthetic rates and biomass yields increase, $\mathrm{N}$ in plant tissues is reduced, and overall ecosystem $\mathrm{C}$ accumulation increases under increased $\mathrm{CO}_{2}$ (Rasse et al. 2005).

Increased salinity by rising sea levels in coastal wetlands tends to lessen the effect of elevated $\mathrm{CO}_{2}$ on plant communities and soils by stressing the plant communities, which counteracts the gains from elevated $\mathrm{CO}_{2}$ (Erickson et al. 2007). However, others have found that productivity gains and soil additions related to responses to elevated $\mathrm{CO}_{2}$ have led to an increase in marsh elevation that have counterbalanced sea level rise (Langley et al. 2009).

A secondary response to elevated $\mathrm{CO}_{2}$ in wetlands is greater $\mathrm{CH}_{4}$ emissions (Vann and Megonigal 2003), although the mechanism of the response is not clear. Vann and Megonigal (2003) speculated that recent elevated carbohydrates (due to higher photosynthetic rates) become available for fermentation through root exudates that drive the methanogen community. Another secondary response of wetlands, especially peatlands, to elevated $\mathrm{CO}_{2}$ is higher production and transport of DOC (Freeman et al. 2004). Similar to the proposed mechanism for elevated $\mathrm{CH}_{4}$ production, higher DOC fluxes result from greater plant production, especially belowground, leading to higher available $\mathrm{C}$ in the soil pore water.

\section{Pollutants and Nutrients in Deposition}

\section{Mercury}

Mercury $(\mathrm{Hg})$ is a toxin that can affect neurological development in animals and humans (Zillioux et al. 1993). The major anthropogenic sources of atmospheric $\mathrm{Hg}$ are coal- and oilfired power plants, gold mining, metal manufacturing, cement production, waste disposal, and caustic soda production (Pirrone et al. 2010). Emissions in North America are declining (Weiss-Penzias et al. 2016) and are currently estimated at $9 \%$ of the global total, compared with $64 \%$ in Asia (Pirrone et al. 2010). Deposition trends within the United States are mixed, with some regions experiencing declines and others experiencing increases, with the latter attributed, at least in part, to long-distance transport from Asia (WeissPenzias et al. 2016).

Mercury that enters wetlands is predominantly in an unreactive form, but it can be transformed via microbial action under anoxic conditions to a readily bioavailable form, methyl mercury, when in wetland soils or sediments. As a result, wetlands can be sinks for total $\mathrm{Hg}$ and major sources of methyl mercury export to freshwater ecosystems (Driscoll et al. 2007; Rudd 1995; St. Louis et al. 1994, 1996). Methyl mercury bioaccumulates in food webs and has a broad range of impacts on aquatic biota (Zillioux et al. 1993).

\section{Sulfur}

The major anthropogenic source of S emissions is fossil fuel combustion and other industrial activities (Klimont et al. 2013). Europe and North America have been experiencing declines over the last two decades as a result of control measures, whereas increases have occurred in the developing world, especially India and China (Klimont et al. 2013; Vet et al. 2014).

Sulfur oxide deposition has multiple effects on wetlands, most notably interactions of the $\mathrm{S}$ with other biogeochemical cycles. In particular, deposition of $\mathrm{S}$ to wetlands can result in an increase in $\mathrm{Hg}$ bioavailability (e.g., Jeremiason et al. 2006), decreases in $\mathrm{CH}_{4}$ production (Dise and Verry 2001; Gauci et al. 2002, 2004; Vile et al. 2003), and decreases in DOC export (de Wit et al. 2007; Montieth et al. 2007; Oulehle et al. 2013). Mercury methylation increases in response to $\mathrm{SO}_{4}{ }^{2-}$ additions to wetlands, presumably by the activity of sulfate-reducing bacteria stimulated by $\mathrm{SO}_{4}{ }^{2-}$ additions (Kolka et al. 2011b). Sulfate-mediated decreases in $\mathrm{CH}_{4}$ production could be reducing the wetland contribution to global climate change (Gauci et al. 2004), and hence declines in $\mathrm{SO}_{4}{ }^{2-}$ deposition could have the unintended consequence of increasing global warming derived from wetland $\mathrm{CH}_{4}$ sources. Similarly, declines in $\mathrm{SO}_{4}{ }^{2-}$ deposition to watersheds could be contributing to observed increasing trends in DOC in streams and lakes of northern North America and Europe (Erlandsson et al. 2008; Montieth et al. 2007).

\section{Nitrogen}

Biologically available $\mathrm{N}$ is deposited primarily as ammonium or nitrate, which may lead to eutrophication and acidification of ecosystems (Galloway et al. 2008). Nitrogen deposition in the United States was historically dominated by nitrate, but recent reductions in nitrate and increases in ammonium deposition have reversed this pattern ( $\mathrm{Li}$ et al. 2016). Wetlands act as major sinks for $\mathrm{N}$, either storing or denitrifying a significant fraction of atmospheric and hydrologic inputs of $\mathrm{N}$ (Baron et al. 2013). As a result of the denitrification process, some of the transformed $\mathrm{N}$ may be released in the form of $\mathrm{N}_{2} \mathrm{O}$, a potent greenhouse gas (Baron et al. 2013). This $\mathrm{N}$ storage and removal capacity is sensitive to hydrologic conditions. Nitrogen deposition can also lead to increased $\mathrm{CH}_{4}$ emissions from peatlands (Aerts and Caluwe 1999), perhaps by shifting plant communities to sedges that transport $\mathrm{CH}_{4}$ from deeper peat (Eriksson et al. 2010; Nykänen et al. 2002).

In nutrient-poor sphagnum (Sphagnum spp.) peatlands, $\mathrm{N}$ deposition has been found to affect both productivity and decomposition, which together largely define the net $\mathrm{C}$ bal- 
ance of peatlands. In these peatlands, the effect of elevated $\mathrm{N}$ deposition on $\mathrm{C}$ balance appears to depend on deposition rate, with increased rates of net $\mathrm{C}$ accumulation in areas of moderate deposition such as eastern Canada (Turunen et al. 2004) but decreased net $C$ accumulation in areas of higher deposition as a result of enhanced decomposition (Bragazza et al. 2006) and reduced sphagnum moss litter production (Bragazza et al. 2012). The negative effects of $\mathrm{N}$ deposition on sphagnum can be at least partially alleviated by higher $\mathrm{P}$ availability (Limpens et al. 2004).

\section{Land Use and Land Management}

Many wetlands have been altered by a variety of land use and land management practices that have affected inherent soil functions and provision of essential ecosystem goods and services. Some of the primary land uses that are associated with wetland alteration include urban and infrastructure development, agriculture, and forest management.

\section{Urban and Infrastructure Development}

Wetlands in urban landscapes are typically confined to detention basins and riparian zones. The surrounding mosaic of impervious surfaces is the principal factor affecting the hydrology and water quality of urban wetlands. However, like other wetlands, urban wetlands act as sponges, retaining excess rainwater and reducing flood risk to nearby homes and businesses. Although wetlands benefit water quality by absorbing many of the pollutants that would otherwise flow directly into rivers, streams, and other water bodies (e.g., pet wastes, pesticides, fertilizers, heavy metals, hydrocarbons, and road salts), they can also be negatively impacted by the volume of pollutants that enter them (Mitsch and Gosselink 2015). Coastal wetlands are particularly at risk from urban development, which can cause excessive nutrient overload from stormwater runoff as well as wastewater treatment effluent that can cause algal blooms in estuarine wetlands (Dahl and Stedman 2013). Excessive loads of heavy metals can also accumulate in wetland soils, causing increased mortality of aquatic animals and increasing risks to public health.

Stormwater runoff that passes over warmed impervious surfaces also increases the water temperature and decreases the amount of dissolved oxygen content. Warmer water with low dissolved oxygen can negatively impact aquatic species and the organisms that depend on them for food, shelter, or both. Additionally, rising water temperatures can increase the release of $\mathrm{P}$ from sediment, further increasing the risk for eutrophication of lakes, ponds, and estuaries (O'Driscoll et al. 2010).
Road and bridge construction across wetlands can cause water impoundment to occur even when culverts are installed, fundamentally changing the wetland hydrology. Construction within a wetland usually leads to an increase in sediment load. This may result in the fragmentation of critical wildlife corridor connectivity and can increase the spread of opportunistic invasive species that thrive in degraded wetlands, leading to further degradation of the soil quality (Czech et al. 2000). Road and bridge maintenance activities and practices can also increase the amount of road salt, herbicides, heavy metal, and many other toxic chemicals that end up in wetlands (Braun and Osterholz 2007).

Similarly, dams have had widespread impacts on associated floodplains and riparian areas by stimulating channel incision, reducing peak flows, elevating low flows, and increasing deposition (King et al. 2012). Levees and dike reduce overbank flooding, thereby changing the hydroperiod for much of a floodplain and, correspondingly, the nature of ecosystem functions. Also, increased flood depths and velocities occur in riparian areas nearest the streams that are not enclosed by the levees, and this can result in scouring and changes in forest species composition. Berms for roads that cross floodplains in a perpendicular angle to the main direction of streamflow may increase flooding (and decrease velocity) on the upstream side while reducing flooding and sheet flow on the downstream side. Consequently, disruption of natural sheet flow on the upper side induces a ponding effect and may cause decreases in forest NPP in response to the damming effect of the berm (Young et al. 1995).

\section{Agriculture}

Many wetlands are associated with agricultural land uses, either directly for cropping and grazing or indirectly when adjacent to cultivated lands. In some instances, wetland hydrology is disrupted through drainage and tillage activities that effectively result in the loss of wetland properties. In other instances, wetlands remain hydrologically intact within, adjacent to, or downstream from agricultural fields and thus receive nutrient-enriched runoff.

\section{Sediment, Nutrient, and Chemical Runoff}

Wetlands nested within, adjacent to, or downstream from agricultural fields tend to receive increased deposition of sediment, nutrients, and agrichemicals through wind and water erosion. These types of impacts have the potential to affect provisioning of various wetland ecosystem services. For example, sedimentation has been shown to affect wetland biotic communities through associated effects (e.g., burial) on plant seed and invertebrate egg banks (Gleason and Euliss 1998; Gleason et al. 2003). Wetlands in cropland settings receive greater amounts of precipitation runoff than 
those in a grassland setting (Euliss and Mushet 1996; van der Kamp et al. 1999, 2003), and upper soil horizons (e.g., O and A horizons) of wetlands with a cropland history have been identified that were overlain by considerable amounts of sediments (exceeding $1 \mathrm{~m}$ ) deposited from adjacent uplands (Tangen and Gleason 2008). A study in the Prairie Pothole Region showed that wetlands surrounded by agricultural lands had five times higher clay and two times higher $\mathrm{P}$ transport rates than wetlands surrounded by grasslands (Martin and Hartman 1987). Elevated soil nitrate concentrations and $\mathrm{N}_{2} \mathrm{O}$ emissions have been identified in cropland associated with wetlands, ostensibly due to inputs of N-based fertilizers (Bedard-Haughn et al. 2006; Tangen et al. 2015). Moreover, various agrichemicals (e.g., herbicides and fungicides) have been identified in sediments and tissues of wetland biota (e.g., Belden et al. 2012; McMurry et al. 2016; Venne et al. 2008). McMurry and others (2016) found that glyphosate concentrations in soils were more than four times greater in cropland wetlands than grassland wetlands. Other major wetland systems of the United States, such as the Florida Everglades (largest subtropical wetland in the United States) and wetlands associated with the Chesapeake Bay (largest estuary in the United States) and the Great Lakes (largest freshwater lakes in the world with over $1200 \mathrm{~km}$ of coast wetlands), receive excessive amounts of $\mathrm{N}, \mathrm{P}$, and $\mathrm{S}$ through fertilizer runoff, causing water quality issues by promoting harmful algal blooms and hypoxia, which can be detrimental to native flora and fauna as well as human health (e.g., contaminated drinking water).

\section{Livestock Grazing}

The impacts of livestock grazing on wetland soils have been shown to be both beneficial and detrimental, depending on the site and grazing management practices. Livestock grazing can directly impact wetland soils through biomass removal, trampling, soil compaction, erosion, altered microtopography, and altered soil nutrient status. Livestock grazing has been found to alter soil $\mathrm{C}$ and $\mathrm{N}$ storage in grasslands. Whether grazing increases or decreases soil $\mathrm{C}$ and $\mathrm{N}$ storage is a matter of debate and in most cases depends on the location of the study and the grazing management system ( $\mathrm{Li}$ et al. 2011). Generally, studies have found that grazing reduces soil nutrient levels (Roberson 1996).

Soil compaction is arguably the most severe impact of livestock grazing, restricting root growth by reducing oxygen availability and space for roots to grow. Soil compaction also reduces the soil infiltration rate, leading to increased rates of precipitation runoff into nearby surface waters. Increased runoff coupled with increased stream bank erosion can cause serious water quality issues. Erosion can lead to channel downcutting and lowered water tables, which affect soil chemistry. However, in cases where keystone herbivores have been removed, livestock soil disturbances have been shown to benefit ephemeral wetlands by controlling invasive species and maintaining a more open canopy (Marty 2005).

\section{Cropland Drainage}

Wetlands have been used for crop production as a result of their naturally high organic $\mathrm{C}$ and nutrient content. However, alteration of the soil aeration is needed to support cropping, and that is accomplished through drainage. This practice of draining wetlands for crop production is the principal cause of wetland loss in the United States. Effectively, the drainage systems remove the hydrologic conditions necessary to support wetland soil processes. One of the most direct impacts of aeration is accelerated respiration that leads to the loss of stored $\mathrm{C}$, as $\mathrm{CO}_{2}$, to the atmosphere. For example, soil $\mathrm{C}$ stores were reduced by up to $50 \%$ when prairie pothole wetlands were converted from native grasslands to croplands (Bedard-Haughn et al. 2006; Gleason et al. 2008, 2009; Tangen et al. 2015), and the effect of drainage on soil loss extends for decades, especially on peatlands (Bridgham et al. 2006). Drainage and tillage also affect soil structure and erosional processes and alter the distribution of nutrients and metals (Skaggs et al. 1994).

\section{Forest Management}

Forest management practices may affect wetlands through disturbance regimes (e.g., harvesting), changes in vegetation community, and alterations of hydrology, and while minor drainage is allowed for silvicultural purposes, it must not alter the wetland status. These disturbance regimes may be imposed singularly or in combination, depending on the forest management objectives. Two types of silvicultural system are typically used in forested wetlands: natural regeneration and plantation management. Stands intended for natural regeneration are either clear-cut or selectively harvested. The effects of harvesting and natural regeneration activities on floodplain functions and soils have been shown to be positive (e.g., in terms of increasing productivity) or neutral (Lockaby et al. 1997). In a comparison of logging practices in bottomland hardwoods, there was no deterioration of hydric soil processes in a red-river bottom (Aust et al. 2006; McKee et al. 2012). If best management practices are followed, studies indicate that there is no change in nutrient source, sink, or transformation relationships or soil productivity. Habitat may be altered for some species of wildlife until canopy closure is regained (Clawson et al. 1997).

In wet pine flats, management may be more intensive and involves site preparation including treatments that reduce wetness in the upper soil, such as bedding. Bedding involves creating an elevated planting bed that is formed by disking soil from shallow trenches $(15-50 \mathrm{~cm})$ on either side of the bed. As a result, the aerated soil volume is greater in a bed- 
ded soil, resulting in enhanced organic matter decomposition and nutrient cycling (Grigal and Vance 2000), and productivity also tends to be higher on beds (Neaves et al. 2017a). While there has been concern about this site preparation method, especially with respect to hydrology, C storage, and nutrient cycling, it has been considered inconsequential for many wetland functions (Harms et al. 1998). Studies in Michigan (Trettin et al. 2011) and South Carolina (Neaves et al. 2017b) on soil property responses to bedding and plantation establishment have shown disturbance effects to be short term (e.g., <20 years).

Minor drainage may also be incorporated into the silvicultural system to reduce the surface water level in advance of harvesting, so soil disturbance is minimized during the logging; the lowered water table may also increase seedling survival and enhance early stand growth (Fox et al. 2015; Skaggs et al. 2016). In the southeastern United States, minor drainage has been incorporated into water management systems, whereby the degree of drainage can be controlled. This enables the imposition of the normal wetland hydrology following stand establishment. While minor silvicultural drainage is allowed under the Clean Water Act, the drainage should not alter the jurisdictional status of the wetland. Most of the minor drainage applications are historical, with current activities primarily limited to ditch cleaning and maintenance. In general, the effects of silvicultural drainage on hydric soils are typically to reduce soil C stocks, particularly on peatlands, and alter greenhouse gas emissions, but productivity may also be enhanced, which can increase soil C (Minkkinen et al. 1999). As a result of the lowered water table, methane emissions are typically lowered and $\mathrm{CO}_{2}$ emissions increase (Moore and Knowles 1989; Nykänen et al. 1998).

\section{Restoration and Mitigation}

Wetland restoration, both freshwater and tidal, is an evolving practice that can be employed to replace wetlands and wetland functions that have been lost on the landscape. While there is no "cookbook" approach for achieving desired performance outcomes due to wetland and regional diversity, there are features common to all wetlands that should be considered when attempting to restore them.

While the number of potential functions and services provided by wetlands is very broad, they can be combined to fall under a small number of categories: hydrologic, soil biogeochemical, habitat, and landscape. The functions that any particular type of wetland can provide can be determined and used to set the restoration project's ecological performance goal(s). The most effective performance goals and criteria are to be SMART (specific, measurable, achievable, results- oriented, and time-fixed); address hydrology, soils, and vegetation; and reflect incremental change. ${ }^{3}$ For voluntary projects that require a permit, the goals as defined in the permit application help to define the benefits of the project, and also its limits. For mitigation and mitigation banks, the goal is to replace what was lost, based on desired functional replacement. Incorporating adaptive management into every step of the process, from planning to design, through construction, completion, and long-term management, can help to optimize achievement of the restoration goals (Stelk et al. 2017).

Reliance on biotic criteria over a short timeframe for measurement of success may create problems establishing achievable performance criteria. Short-term monitoring data can describe initial conditions and suggest a site's potential for sustaining itself, but a long-term management plan is needed to ensure that the site remains on its trajectory (Kolka et al. 2000). In recent years, there has been increasing recognition that longer monitoring timeframes and measurement of abiotic and biotic performance are likely to yield more reliable indicators of progress toward meeting project goals (Environmental Law Institute 2004; Kusler 2006). A longer process is critical to building healthy wetland soils that, in turn, improve the potential for native wetland vegetation to persist over time and reduce vulnerability to invasive species. For example, in restoring longleaf pine (Pinus palustris) wet savannas, managers opted to leave slash pine plantations in place to build up litter to carry ground fires that are needed to manage the target longleaf pine (a tree that lives upwards of 300 years) (Kirkman et al. 2001).

Consistently, the single most often cited reason for wetland restoration project failure is the inability to correctly assess the restoration site and plan a wetland restoration that could be achieved on that site. Hydrologic sources and constraints, onsite and offsite stressors, soil compaction, and other factors should be examined before determining what kinds of wetland or stream restoration are achievable at a specific location. If the site is not properly assessed, then the design, plan, and onsite construction actions will not achieve the desired outcomes. Thoroughly researching soil condition is imperative (Stelk et al. 2017). In 1998-1999, an estimated 676 birds died in the North Shore Restoration Area of Lake Apopka in Florida after the surrounding farmland was restored. The restoration was focused on reflooding the farm

\footnotetext{
${ }^{3}$ SMART does not have a universal definition, and the words within the acronym have changed over time to fit the specific situation. It was first coined in 1981 by George T. Doran, a consultant and former Director of Corporate Planning for Washington Water Power Company, in a published paper titled "There's a S.M.A.R.T. Way to Write Management's Goals and Objectives." Here we use the terms and definitions recommended by Peter Skidmore in a 2017 white paper on wetland restoration (Stelk et al. 2017).
} 
fields and the elimination or breaching of the levees that separated the fields from the main body of the lake. Organochlorine pesticide residues remained in the soils and ended up accumulating in the fish that the birds were eating, which caused the mortality event (Industrial Economics 2004).

Another important consideration regarding wetland soils and restoration is $\mathrm{C}$ storage. In general, the more the water table is lowered, the faster soil $\mathrm{C}$ is lost (Couwenberg et al. 2009). Dry wetland soils (e.g., peatlands) are also susceptible to frequent fires that can further cause large soil $\mathrm{C}$ losses (Turetsky et al. 2011).

Restoration strongly modifies hydrology and vegetation of restored wetlands, which directly influences soil properties. Restoring wetlands has been found to reverse the loss of soil C from draining (Järveoja et al. 2016). For instance, restored mineral soil wetlands in the Prairie Pothole Region accumulated $0.74 \mathrm{Mg} \mathrm{C}^{-1}$ year $^{-1}$ over a 55 -year period (Ballantine and Schneider 2009). Guidelines from the Intergovernmental Panel on Climate Change for mineral soil wetlands state that cultivation leads to losses of up to $71 \%$ of the soil organic $\mathrm{C}$ in the top $30 \mathrm{~cm}$ of soil over 20 years, and restoration increases depleted soil $\mathrm{C}$ stocks by $80 \%$ over 20 years and by $100 \%$ after 40 years (Wickland et al. 2014). An increase in soil $\mathrm{C}$ is also regularly measured after restoring organic soil wetlands (Lucchese et al. 2010). Projects that restore or preserve soil $\mathrm{C}$ pools in tidal wetlands can be issued $\mathrm{C}$ credits through voluntary and regulatory programs (Emmett-Mattox et al. 2011).

Wetland restoration typically lowers DOC export from wetlands (Strack and Zuback 2013); however, there may be an initial flush after restoration activities. Rewetting or creating freshwater wetlands may increase $\mathrm{CH}_{4}$ emissions (Badiou et al. 2011; Strack and Zuback 2013), although some studies have found that restoration did not increase $\mathrm{CH}_{4}$ emissions (Richards and Craft 2015). Methane emissions appear to be especially high in restored wetlands located in agricultural settings or in deep water areas with emergent vegetation (SchrierUijl et al. 2014; Strack and Zuback 2013). In the long term, the climate benefits of increasing soil $\mathrm{C}$ sequestration through restoring degraded wetlands appear to be a positive for greenhouse gas mitigation (Strack and Zuback 2013), especially in saline tidal wetlands where the presence of sulfate in floodwater suppresses $\mathrm{CH}_{4}$ production (Poffenbarger et al. 2011).

In addition to improving greenhouse gas mitigation, wetland restoration also has the potential to modify soil physical properties (Price et al. 2003). For instance, degraded wetlands are often compacted, with high bulk density and low hydraulic conductivity (Wüst-Galley et al. 2016), but restoration has been found to reverse that trend (Ballantine and Schneider 2009). However, the timeframe for soil restoration is much longer and may take many decades compared to other ecosystem components such as hydrology and vegeta- tion that can recover in months to years (Lucchese et al. 2010; Schimelpfenig et al. 2014).

\section{Tools}

Interest in modeling wetland soil processes developed as researchers considered ecological processes (Mitsch 1988). Subsequently, models to consider nutrient removal in riparian zones (e.g., Lowrance et al. 2000), C cycling (e.g., Zhang et al. 2002), and peat accumulation (Frolking et al. 2010) have been developed, and recently USDA published a framework for $\mathrm{C}$ accounting in managed wetlands (Ogle et al. 2014). A major consideration for models applicable to hydric soils is the ability to consider anaerobic conditions explicitly, as it is mediated by water table, soil moisture, inherent soil physical and chemical properties, and vegetation. However, many wetland soil models take a simpler or nonmechanistic approach (Trettin et al. 2001). Correspondingly, the extent to which wetland hydrology is characterized in models varies widely. For most of the models, estimates of wetland hydrology are only based on precipitation and potential evapotranspiration. Few models consider groundwater input or lateral flow. Accordingly, the functionality to estimate DOC and inorganic $\mathrm{C}$, as well as dissolved nutrient transport, is lacking.

To consider the role of wetlands on the nutrient and $\mathrm{C}$ cycling, water quality, and hydrology of a watershed or other large area, the wetland must be functionally integrated with adjoining ecosystems and water bodies. This implies then that a watershed-scale model is needed to simulate the hydrologic conditions throughout the watershed so that the biogeochemical processes within the uplands and wetlands reflect the hydrologic conditions within the component ecosystems. The challenge is that modeling watershed hydrology is a difficult endeavor, hence warranting dedicated hydrologic models; accordingly, incorporating watershed hydrology is beyond the scope of most existing biogeochemical models. Dai and others (2011) used a linked modeling framework to address this issue at the watershed scale, running the hydrologic simulation using the MIKE SHE modeling system and taking that response to drive the soil biogeochemistry simulation in the forest denitrification-decomposition (ForestDNDC) model. That study demonstrated the importance of considering the wetland biogeochemistry explicitly to characterize the $\mathrm{C}$ balance, even though wetlands make up only a portion of the watershed.

Conversely, watershed-scale models are available to assess nutrient and $\mathrm{C}$ cycling and are typically applied to manage watersheds or basins. The Soil Water Assessment Tool (SWAT) is a continuation of models developed by the USDA Agricultural Research Service (USDA ARS) (Arnold et al. 2012) designed to simulate hydrology and nutrient 
loads within a basin. However, it was developed primarily for uplands and typically operates at large scales that obscure the presence of wetlands. Currently, modifications to SWAT that explicitly consider anaerobic soil conditions and shallow water tables are being developed. In contrast, the Riparian Ecosystem Management Model (REMM), also developed by USDA ARS, facilitates assessments of uplands and riparian zones, including wetlands and streams, on a small scale. The Soil and Water Integrated Model (SWIM) is another semispatially distributed model capable of assessing the contributions of wetlands to regional-scale hydrology and nutrient cycling (Hatterman et al. 2008).

\section{Key Findings}

- Wetland soil processes are different from those of upland soils and inextricably linked to the hydrologic regime of the site and the vegetation; hence they are sensitive to changes in environmental conditions and management regimes. Organic and mineral wetland soils exhibit distinct physical and chemical properties.

- While wetlands account for a relatively small portion of the terrestrial landscape, they provide highly valued ecosystem services that are largely mediated by soil processes, including water purification and $\mathrm{C}$ sequestration. However, these services are dependent on stability of the hydrologic regime, so changes in hydrology driven by climate, drainage, or other disturbances can eliminate key functions and services (e.g., turning peatlands from a net $\mathrm{C}$ sink to a source). Similarly, changes in the chemical environment (e.g., from air or water pollution) can overwhelm or eliminate key services like water purification.

- Wetlands are sensitive to changes in temperature, moisture regime, and external inputs, whereby altered soil processes and vegetative communities may be expected to alter functions and hence ecosystem services.

- Wetland restoration can offset loss of natural wetlands. However, functional wetland restoration requires a comprehensive assessment of site and environmental conditions as the foundation for an adaptive management plan to ensure long-term viability of the system.

\section{Key Information Needs}

- Soil processes of tidal freshwater wetlands, especially forests, are not well understood as a result of the complex hydrologic setting mediated by tidal and terrestrial processes. This information is important because these wetlands are at the interface of the changing sea level and commonly occur within rapidly urbanizing regions (e.g., southeastern United States). Watershed-scale studies are needed that focus on the dynamics and transfer of organic matter, nutrients, and chemicals through tidal freshwater wetlands and the linkages to adjoining uplands and tidal waters.

- There is considerable uncertainty whether hydric soil processes in restored wetlands are comparable to natural systems after the establishment phase, thereby providing the capacity to provision ecosystem services. This gap exists because of the paucity of long-term monitoring data. Accordingly, long-term monitoring of restored sites across the gradient of common wetland types is warranted.

- Silvicultural drainage systems must sustain functional properties of the wetland; however, there are uncertainties about the interactions of management regimes, climate, and stand development on the functionality of pine plantations in wetlands. Assessment of long-term response of soil processes in forested wetlands where silvicultural drainage has been used is needed. Opportunities should focus on established ( $>10$ years) sites that have some prior information from studies or monitoring that could provide a foundation for further assessment, with the goal being to better understand long-term responses to ensure sustainability.

- There is a need for manipulation experiments to assess the interactions of management regimes and extreme events on wetland soil processes that affect surface water quality. Particularly important are systems sensitive to mercury methylation, nutrient loading, and burning.

- Although pools of $\mathrm{C}$ are important to measure, we need more $\mathrm{CO}_{2}$ and $\mathrm{CH}_{4}$ measurements to understand both temporal and spatial variation in greenhouse gas fluxes and how change (e.g., both land use and climate) is influencing those fluxes.

- The interactions of key wetland ecosystem and soil stressors such as climate change, air pollution, disturbances like fire, and land use change may interact in ways that are hard to predict and, in combination, could have important unforeseen impacts on wetland functions and services. This knowledge gap speaks to the need for robust, process-based models to better understand uncertainties and risks so that management and protective measures may be developed. Robust mechanistic models that predict soil biogeochemical processes in response to changing environmental conditions and management regimes are needed to provide tools for assessing and managing ecosystem services. 


\section{Literature Cited}

Aerts R, de Caluwe H (1999) Nitrogen deposition effects on carbon dioxide and methane emissions from temperate peatland soils. Oikos 84(1):44-54

Alongi DM (2014) Carbon cycling and storage in mangrove forests. Annu Rev Mar Sci 6:195-219

Amatya DM, Harrison CA, Trettin CC (2016) Hydro-meteorologic assessment of October 2015 extreme precipitation event on Santee Experimental Forest watersheds. J S C Water Resour 3(1):19-30

Anderson C, Lockaby BG (2007) Soils and biogeochemistry of tidal freshwater forested wetlands. In: Conner WH, Doyle TW, Krauss KW (eds) Ecology of tidal freshwater forested wetlands of the southeastern United States. Springer, Dordrecht, pp 65-88

Armitage AR, Highfield WE, Brody SD, Louchouarn P (2015) The contribution of mangrove expansion to salt marsh loss on the Texas Gulf Coast. PLoS One 10:e0125404

Arnold JG, Moriasi DN, Gassman PM et al (2012) SWAT: model use, calibration and validation. Trans Am Soc Agric Biol Eng 55:1491-1508

Aust WM, Fristoe TC, Gellerstedt LA et al (2006) Long-term effects of helicopter and ground-based skidding on soil properties and stand growth in a tupelo-cypress wetland. For Ecol Manag 226:72-79

Badiou P, McDougal R, Pennock D, Clark B (2011) Greenhouse gas emissions and carbon sequestration potential in restored wetlands of the Canadian prairie pothole region. Wetl Ecol Manag 19:237-256

Ballantine K, Schneider R (2009) Fifty-five years of soil development in restored freshwater depressional wetlands. Ecol Appl 19:1467-1480

Bansal S, Tangen B, Finocchiaro R (2016) Temperature and hydrology affect methane emissions from prairie pothole wetlands. Wetlands 36(supplement 2):371-381

Baron JS, Hall EK, Nolan BT et al (2013) The interactive effects of excess reactive nitrogen and climate change on aquatic ecosystems and water resources of the United States. Biogeochemistry 114(1-3):71-92

Bartlett KB, Bartlett DS, Harriss RC, Sebacher DI (1987) Methane emissions along a salt marsh salinity gradient. Biogeochemistry 4:183-202

Batt BDJ, Anderson MG, Anderson CD, Caswell FD (1989) The use of prairie potholes by North American Ducks. In: van der Valk AG (ed) Northern prairie wetlands. Iowa State University Press, Ames, pp 204-227

Beauchamp SK (1996) Cypress: from wetlands and wildlife habitat to flowerbeds and front yards. University of Florida, Institute of Food and Agricultural Sciences, Gainesville

Bedard-Haughn A, Matson AL, Pennock DJ (2006) Land use effects on gross nitrogen mineralization, nitrification, and $\mathrm{N}_{2} \mathrm{O}$ emissions in ephemeral wetlands. Soil Biol Biochem 38:3398-3406

Beeri O, Phillips RL (2007) Tracking palustrine water seasonal and annual variability in agricultural wetland landscapes using Landsat from 1997 to 2005. Glob Chang Biol 13:897-912

Belden JB, Hanson B, McMurry ST et al (2012) Assessment of the effects of farming and conservation programs on pesticide deposition in High Plains wetlands. Environ Sci Technol 46:3424-3432

Bergstrom JC, Stoll JR, Titre JP, Wright VL (1990) Economic value of wetlands-based recreation. Ecol Econ 2:129-147

Bragazza L, Freeman C, Jones T et al (2006) Atmospheric nitrogen deposition promotes carbon loss from peat bogs. Proc Natl Acad Sci 103(51):19386-19389

Bragazza L, Buttler A, Habermacher J et al (2012) High nitrogen deposition alters the decomposition of bog plant litter and reduces carbon accumulation. Glob Chang Biol 18(3):1163-1172
Brander LM, Florax RJGM, Vermaat JE (2006) The empirics of wetland valuation: a comprehensive summary and a meta-analysis of the literature. Environ Resour Econ 33:223-250

Braun RJ, Osterholz LC (eds) (2007) Indiana storm water quality manual. Indiana Department of Environmental Management, Indianapolis, $15 \mathrm{p}$

Bridgham SD, Johnston CA, Pastor J, Updegraff K (1995) Potential feedbacks of northern wetlands on climate change. Bioscience 45:262-274

Bridgham SD, Megonigal JP, Keller JK et al (2006) The carbon balance of North American wetlands. Wetlands 26:889-916

Bridgham SD, Cadillo-Quiroz H, Keller JK, Zhuang Q (2013) Methane emissions from wetlands: biogeochemical, microbial, and modeling perspectives from local to global scales. Glob Chang Biol 19:1325-1346

Burkett V, Kusler J (2000) Climate change: potential impacts and interactions in wetlands of the United States. J Am Water Resour Assoc 36:313-320

Caraco NF, Cole JJ, Likens GE (1989) Evidence for sulfate-controlled phosphorus release from sediments of aquatic systems. Nature 341:316-318

Carter V (1990) The Great Dismal Swamp: an illustrated case study. In: Lugo AE, Brinson M, Brown S (eds) Ecosystems of the world 15: forested wetlands. Elsevier, Amsterdam, pp 201-211

Chambers RM, Odum WE (1990) Porewater oxidation, dissolved phosphate and the iron curtain. Biogeochemistry 10:37-52

Charles H, Dukes JS (2009) Effects of warming and altered precipitation on plant and nutrient dynamics of a New England salt marsh. Ecol Appl 19:1758-1773

Chmura GL, Anisfeld SC, Cahoon DR, Lynch JC (2003) Global carbon sequestration in tidal, saline wetland soils. Glob Biogeochem Cycles 17(4):1111

Clair TA, Warner BG, Roberts R et al (1995) Canadian inland wetlands and climate change. In: Environment Canada (ed) Canadian country study: climate impacts and adaptations. Environment Canada, Ottawa, pp 189-218

Clawson RG, Lockaby BG, Jones R (1997) Amphibian responses to helicopter harvesting in forested floodplains of low order, blackwater streams. For Ecol Manag 90(2-3):225-236

Clewley D, Whitcomb J, Moghaddam M et al (2015) Evaluation of ALOS PALSAR data for high-resolution mapping of vegetated wetlands in Alaska. Remote Sens 7:7272-7297

Clough BF, Andrews TJ, Cowan IR (1982) Physiological processes in mangroves. In: Clough BF (ed) Mangrove ecosystems in Australia: structure, function and management. Australian National University Press, Canberra, pp 193-210

Conner WH, Buford MA (1998) Southern deepwater swamps. In: Messina MG, Conner WH (eds) Southern forested wetlands: ecology and management. CRC Press, Boca Raton, pp 261-287

Couwenberg J, Dommain R, Joosten H (2009) Greenhouse gas fluxes from tropical peatlands in south-east Asia. Glob Chang Biol 16:1715-1732

Cowardin LM, Carter V, Golet FC, LaRoe ET (1979) Classification of wetlands and deepwater habitats of the United States, Report FWS/OBS-79/31. U.S. Department of the Interior, Fish and Wildlife Service, Washington, DC. http://www.fws.gov/wetlands/ Documents/classwet/index.html. Accessed 5 Apr 2019

Craft CB (2001) Biology of wetland soils. In: Richardson JL, Vepraskas MJ (eds) Wetland soils. Lewis Publishers, Boca Raton, pp 107-136

Craft CB (2007) Freshwater input structures soil properties, vertical accretion and nutrient accumulation of Georgia and United States (U.S.) tidal marshes. Limnol Oceanogr 52:1220e1230

Creed IF, Miller J, Aldred D et al (2013) Hydrologic profiling for greenhouse gas effluxes from natural grasslands in the Prairie Pothole Region of Canada. J Geophys Res Biogeosci 118:680-697 
Creel M, Loomis J (1992) Recreation value of water to wetlands in the San Joaquin Valley: linked multinomial logit and count data trip frequency models. Water Resour Res 28(10):2597-2606

Currin CA, Newell SY, Paerl HW (1995) The role of standing dead Spartina alterniflora and benthic microalgae in salt marsh food webs: considerations based on multiple stable isotope analysis. Mar Ecol Prog Ser 121:99-116

Czech B, Krausman PR, Devers PK (2000) Economic associations among causes of species endangerment in the United States. Bioscience 50(7):593-601

D’Angelo EM, Reddy KR (1999) Regulators of heterotrophic microbial potentials in wetland soils. Soil Biol Biochem 31:815-830

Dahl TE (1990) Wetlands losses in the United States: 1780's to 1980's. U.S. Department of the Interior, Fish and Wildlife Service, Washington, DC, 13 p. Available at: http://www.fws.gov/wetlands/ Status-And-Trends/index.html. Accessed 5 Apr 2019

Dahl TE (2011) Status and trends of wetlands in the conterminous United States 2004 to 2009. U.S. Department of the Interior, Fish and Wildlife Service, Washington, DC, 108 p. Available at: http:// www.fws.gov/wetlands/Status-And-Trends/index.html. Accessed 5 Apr 2019

Dahl TE (2014) Status and trends of prairie wetlands in the United States 1997 to 2009. U.S. Fish and Wildlife Service, Washington, DC. Available at http://www.fws.gov/wetlands/Status-And-Trends/ index.html. Accessed 5 Apr 2019

Dahl TE, Stedman SM (2013) Status and trends of wetlands in the coastal watersheds of the conterminous United States 2004 to 2009. U.S. Department of the Interior, Fish and Wildlife Service and National Oceanic and Atmospheric Administration, National Marine Fisheries Service. 46 p. Available at: http://www.fws. gov/wetlands/Status-And-Trends/index.html. Accessed 5 Apr 2019

Dai Z, Trettin CC, Li C et al (2011) Effect of assessment scale on spatial and temporal variations in $\mathrm{CH}_{4}, \mathrm{CO}_{2}$, and $\mathrm{N}_{2} \mathrm{O}$ fluxes in a forested wetland. Water Air Soil Pollut 223(1):253-265

Dalcin Martins P, Hoyt DW, Bansal S et al (2017) Abundant carbon substrates drive extremely high sulfate reduction rates and methane fluxes in prairie pothole wetlands. Glob Chang Biol 23(8):3107-3120

Das S, Crepin AS (2013) Mangroves can protection against wind during storms. Estuar Coast Shelf Sci 134:98-107

Davidson EA, Janssen IA (2006) Temperature sensitivity of soil decomposition and feedbacks to climate change. Nature 440:165-173

Day JW, Christian RR, Boesch DM et al (2008) Consequences of climate change on the ecogeomorphology of coastal wetlands. Estuar Coasts 31:477-491

de Groot R, Brander L, van der Ploeg S et al (2012) Global estimates of the value of ecosystems and their services in monetary units. Ecosyst Serv 1(1):50-61

De Wit HA, Mulder J, Hindar A, Hole L (2007) Long-term increase in dissolved organic carbon in streamwaters in Norway is response to reduced acid deposition. Environ Sci Technol 41(22):7706-7713

Dise NB, Verry ES (2001) Suppression of peatland methane emission by cumulative sulfate deposition in simulated acid rain. Biogeochemistry 53(2):143-160

Donato DC, Kauffman JB, MacKenzie A et al (2012) Whole-island carbon stocks in the tropical Pacific: implications for mangrove conservation and upland restoration. J Environ Manag 97:89-96

Doss CR, Taff SJ (1996) The influence of wetland type and wetland proximity on residential property values. J Agric Resour Econ 21:120-129

Drake BG, Muehe MS, Peresta G et al (1996) Acclimation of photosynthesis, respiration and ecosystem carbon flux of a wetland on Chesapeake Bay, Maryland to elevated atmospheric $\mathrm{CO}_{2}$ concentration. Plant Soil 187(2):111-118
Driscoll CT, Han YJ, Chen CY et al (2007) Mercury contamination in forest and freshwater ecosystems in the northeastern United States. Bioscience 57(1):17-28

O'Driscoll M, Clinton S, Jefferson A, Manda A, McMillan S (2010) Urbanization effects on watershed hydrology and in-stream processes in the Southern United States. Water 2(3):605-648

Duarte CM, Middelburg JJ, Caraco N (2005) Major role of marine vegetation on the oceanic carbon cycle. Biogeosciences 2:1-8

Easterling DR, Kunkel KE, Arnold JR et al (2017) Precipitation change in the United States. In: Wuebbles DJ, Fahey DW, Hibbard KA et al (eds) Climate science special report: fourth national climate assessment, vol I. U.S. Global Change Research Program, Washington, DC, pp 207-230

Ehrenfeld J (2012) Northern red maple and black ash swamps. In: Batzer DP, Baldwin AH (eds) Wetland habitats of North America: ecology and conservation concerns. University of California Press, Berkeley

Ellison AM (2000) Mangrove restoration: do we know enough? Restor Ecol 8:219-229

Emmett-Mattox S, Crooks S, Findsen J (2011) Gases and grasses: the restoration, conservation, or avoided loss of tidal wetlands carbon pools may help to mitigate climate change. Environ Forum 28:30-35

Environmental Law Institute (2004) Measuring mitigation: a review of the science for compensatory mitigation performance standards. Environmental Law Institute ${ }^{\circledR}$, Washington, DC. Report prepared for U.S. Environmental Protection Agency. https://www.eli.org/ sites/default/files/eli-pubs/revision.pdf. Accessed 5 Apr 2019

Erickson JE, Megonigal JP, Peresta G, Drake BG (2007) Salinity and sea level mediate elevated $\mathrm{CO}_{2}$ effects on $\mathrm{C} 3-\mathrm{C} 4$ plant interactions and tissue nitrogen in a Chesapeake Bay tidal wetland. Glob Chang Biol 13:202-215

Eriksson T, Öquist MG, Nilsson MB (2010) Effects of decadal deposition of nitrogen and sulfur, and increased temperature, on methane emissions from a boreal peatland. J Geophys Res 115:G04036. https://doi.org/10.1029/2010JG001285

Erlandsson M, Buffam I, Fölster J et al (2008) Thirty-five years of synchrony in the organic matter concentrations of Swedish rivers explained by variation in flow and sulphate. Glob Chang Biol 14(5):1191-1198

Eslami-Andargoli L, Dale P, Sipe N, Chaseling J (2009) Mangrove expansion and rainfall patterns in Moreton Bay, Southeast Queensland, Australia. Estuar Coast Shelf Sci 85:292-298

Euliss NH Jr, Mushet DM (1996) Water-level fluctuation in wetlands as a function of landscape condition in the prairie pothole region. Wetlands 16:587-593

Euliss NH Jr, Wrubleski DA, Mushet DM (1999) Wetlands of the prairie pothole region: invertebrate species composition, ecology, and management. In: Batzer DP, Rader RB, Wissinger SA (eds) Invertebrates in freshwater wetlands of North America: ecology and management. Wiley, New York, pp 471-514

Euliss NH Jr, LaBaugh JW, Fredrickson LH et al (2004) The wetland continuum: a conceptual framework for interpreting biological studies. Wetlands 24:448-458

Euliss NH Jr, Gleason RA, Olness A et al (2006) North American prairie wetlands are important nonforested land-based carbon storage sites. Sci Total Environ 361:179-188

Euliss NH Jr, Mushet DM, Newton WE et al (2014) Placing prairie pothole wetlands along spatial and temporal continua to improve integration of wetland function in ecological investigations. J Hydrol 513:490-503

Feierabend SJ, Zelazny JM (1987) Status report on our Nation's wetlands. National Wildlife Federation, Washington, DC, $50 \mathrm{p}$

Fenner N, Freeman C (2011) Drought-induced carbon loss in peatlands. Nat Geosci 4(12):895-900

Field CD (1995) Impact of expected climate change on mangroves. Hydrobiologia 295:75-81 
Finocchiaro R, Tangen B, Gleason R (2014) Greenhouse gas fluxes of grazed and hayed wetland catchments in the U.S. Prairie Pothole Ecoregion. Wetl Ecol Manag 22:305-324

Flannigan M, Stocks B, Turetsky M, Wotton M (2009) Impacts of climate change on fire activity and fire management in the circumboreal forest. Glob Chang Biol 15:549-560

Flynn K (1996) Understanding wetlands and endangered species: definitions and relationships, Extension Publication ANR-979. Alabama Cooperative Extension System, Florence, 6 p

Fox TR, Jokela EJ, Allen HL (2015) Pine plantation silviculture in the southern United States. In: Rauscher HM, Johnsen K (eds) Southern forest science: past, present, and future, General Techniocal Report SRS-GTR-075. U.S. Department of Agriculture, Forest Service, Southern Research Station, Asheville, pp 63-82

Freeman C, Fenner N, Ostle NJ et al (2004) Export of dissolved organic carbon from peatlands under elevated carbon dioxide levels. Nature 430:195-198

Frey EF, Palin MB, Walsh PJ, Whitcraft CR (2013) Spatial Hedonic valuation of a multiuse urban wetland in Southern California. Agric Resour Econ Rev 42(2):387-402

Frolking S, Roulet NT, Tuittila E et al (2010) A new model of Holocene peatland net primary production, decomposition, water balance, and peat accumulation. Earth Syst Dynam 1:1-21

Furch K (1997) Chemistry of Várzea and Igapó soils and nutrient inventory of their floodplain forests. In: Junk WJ (ed) The Central Amazon floodplain: ecology of a pulsing system, Ecological Studies 126. Springer, Berlin, pp 47-67

Furukawa K, Wolanski E, Mueller H (1997) Currents and sediment transport in mangrove forests. Estuar Coast Shelf Sci 44(3):301-310

Furumai H, Kawasaki T, Futuwatari T, Kusuda T (1988) Effect of salinity on nitrification in a tidal river. Water Sci Technol 20:165-174

Galloway JN, Townsend AR, Erisman JW et al (2008) Transformation of the nitrogen cycle: recent trends, questions, and potential solutions. Science 320(5878):889-892

Gariano SL, Guzzetti F (2016) Landslides in a changing climate. Earth Sci Rev 162:227-252

Gauci V, Dise N, Fowler D (2002) Controls on suppression of methane flux from a peat bog subjected to simulated acid rain sulfate deposition. Glob Biogeochem Cycles 16(1):4-1-4-12

Gauci V, Matthews E, Dise N et al (2004) Sulfur pollution suppression of the wetland methane source in the 20th and 21st centuries. Proc Natl Acad Sci 101(34):12583-12587

Gedan KB, Bertness MD (2009) Experimental warming causes rapid loss of plant diversity in New England salt marshes. Ecol Lett 12:842-848

Gedan KB, Kirwan ML, Wolanski E et al (2011) The present and future role of coastal wetland vegetation in protecting shorelines: answering recent challenges to the paradigm. Clim Chang 106(1):7-29

Gleason RA, Euliss NH Jr (1998) Sedimentation of prairie wetlands. Great Plains Res 8:97-112

Gleason RA, Euliss NH Jr, Hubbard DE, Duffy WG (2003) Effects of sediment load on emergence of aquatic invertebrates and plants from wetland soil egg and seed banks. Wetlands 23:26-34

Gleason RA, Laubhan MK, Euliss NH Jr (eds) (2008) Ecosystem services derived from wetland conservation practices in the United States Prairie Pothole Region with an emphasis on the U.S. Department of Agriculture Conservation Reserve and Wetlands Reserve Programs, U.S. Geological Professional Paper 1745. U.S. Department of the Interior, Geological Survey, Reston, $58 \mathrm{p}$

Gleason RA, Tangen BA, Browne BA, Euliss NH Jr (2009) Greenhouse gas flux from cropland and restored wetlands in the Prairie Pothole Region. Soil Biol Biochem 41:2501-2507

Goldhaber MB, Mills CT, Morrison JM et al (2014) Hydrogeochemistry of prairie pothole region wetlands: role of long-term critical zone processes. Chem Geol 387:170-183
Goldhaber MB, Mills CT, Mushet DM et al (2016) Controls on the geochemical evolution of Prairie Pothole Region lakes and wetlands over decadal time scales. Wetlands 36(supplement 2):S255-S272

Gosselink JG, Turner RE (1978) The role of hydrology in freshwater wetland ecosystems. In: Good RE, Whigham DF, Simpson RL (eds) Freshwater wetlands. Academic, London, pp 63-78

Griffis TJ, Rouse WR, Waddington JM (2000) Interannual variability of net $\mathrm{CO}_{2}$ exchange at a subarctic fen. Glob Biogeochem Cycles 14:1109-1121

Grigal DF, Vance ED (2000) Influence of soil organic matter on forest productivity. N Z J For Sci 30:169-205

Groisman PY, Knight RW, Easterling DR et al (2005) Trends in intense precipitation in the climate record. J Clim 18(9):1326-1350

Groisman PY, Knight RW, Karl TR (2012) Changes in intense precipitation over the central United States. J Hydrometeorol 13(1):47-66

Harms WR, Aust WM, Burger JA (1998) Wet flatwoods. In: Messina MG, Conner WH (eds) Southern forested wetlands: ecology and management. CRC Press, Boca Raton

Hatterman F, Krysanova V, Hesse C (2008) Modeling wetland processes in regional applications. Hydrol Sci J 53(5):1001-1012

Hayashi M, van der Kamp G, Rosenberry DO (2016) Hydrology of prairie wetlands: understanding the integrated surface-water and groundwater processes. Wetlands 36(supplement 2):S237-S254

Hemond HF, Beniot J (1988) Cumulative impacts on water quality functions of wetlands. Environ Manag 12(5):639-653

Hey DL, McGuiness D, Beorkem MN et al (2002) Flood damage reduction in the upper Mississippi River basin: an ecological means. McKnight Foundation, Minneapolis, $37 \mathrm{p}$

Hodges JD (1998) Minor alluvial floodplains. In: Messina MG, Conner WH (eds) Southern forested wetlands: ecology and management. CRC Press, Boca Raton

Howarth RW (1988) Nutrient limitation of net primary production in marine ecosystems. Annu Rev Ecol Syst 19:89-110

Hyvonen R, Agren GI, Linder S et al (2007) The likely impact of elevated $\left[\mathrm{CO}_{2}\right]$, nitrogen deposition, increased temperature and management on carbon sequestration in temperate and boreal forest ecosystems: a literature review. New Phytol 173(3):463-480

ICF International (2013) Greenhouse gas mitigation options and costs for agricultural land and animal production within the United States, Report prepared for U.S. Department of Agriculture, Climate Change Program Office under Contract No. AG-3142-P-10-0214. ICF International, Washington, DC

Industrial Economics, Inc (2004) Final Lake Apopka natural resource damage assessment and restoration plan, Final Report prepared for U.S. Department of the Interior, Fish and Wildlife Service. Industrial Economics, Inc./The St. Johns River Water Management District, Cambridge, MA/Palatka

Järveoja J, Peichl M, Maddison M et al (2016) Impact of water table level on annual carbon and greenhouse gas balances of a restored peat extraction area. Biogeosciences 13:2637-2651

Jenkins WA, Murray BC, Kramer RA, Faulkner SP (2010) Valuing ecosystem services from wetlands in the Mississippi alluvial valley. Ecol Econ 9:1051-1061

Jeremiason JD, Engstrom DR, Swain EB et al (2006) Sulfate addition increases methylmercury production in an experimental wetland. Environ Sci Technol 40(12):3800-3806

Johnson DW (2006) Progressive N limitation in forests: review and implications for long-term responses to elevated $\mathrm{CO}_{2}$. Ecology 87(1):64-75

Johnson WC, Poiani KA (2016) Climate change effects on prairie pothole wetlands: findings from a twenty-five year numerical modeling project. Wetlands 36:273-285

Johnson WC, Boettcher SE, Poiani KA, Guntenspergen G (2004) Influence of weather extremes on the water levels of glaciated prairie wetlands. Wetlands 24(2):385-398 
Johnson WC, Millett BV, Gilmanov T (2005) Vulnerability of Northern Prairie wetlands to climate change. Bioscience 55(10):863-872

Johnston CA, Detenbeck NE, Neimi GJ (1990) The cumulative effects of wetlands on stream water quality and quantity: a landscape approach. Biogeochemistry 10:105-141

Kadlec RH, Wallace SD (2009) Treatment wetlands, 2nd edn. CRC Press, Boca Raton, $366 \mathrm{p}$

Kasischke ES, Turetsky MR (2006) Recent changes in the fire regime across the North American boreal region-spatial and temporal patterns of burning across Canada and Alaska. Geophys Res Lett 33:L09703

Kelleway JJ, Saintilan N, Macreadie PI et al (2016) Seventy years of continuous encroachment substantially increases 'blue carbon' capacity as mangroves replace intertidal salt marshes. Glob Chang Biol 22:1097-1109

King SL, Battaglia LL, Hupp R et al (2012) Floodplain wetlands of the Southeastern coastal plain. In: Batzer DP, Baldwin AH (eds) Wetland habitats of North America: ecology and conservation concerns. University of California Press, Berkeley

Kirkman LK, Mitchell RJ, Helton RC, Drew MB (2001) Productivity and species richness across an environmental gradient in a firedependent ecosystem. Am J Bot 88:2119-2128

Kirwan ML, Megonigal JP (2013) Tidal wetland stability in the face of human impacts and sea-level rise. Nature 504:53-60

Kirwan ML, Mudd SM (2012) Response of salt-marsh carbon accumulation to climate change. Nature 489:550-553

Kirwan ML, Guntenspergen GR, Morris JT (2009) Latitudinal trends in Spartina alterniflora productivity and the response of coastal marshes to global change. Glob Chang Biol 15:1982-1989

Kirwan ML, Langley JA, Guntenspergen GR, Megonigal JP (2013) The impact of sea-level rise on organic matter decay rates in Chesapeake Bay brackish tidal marshes. Biogeosciences 10:1869-1876

Klimont Z, Smith SJ, Cofala J (2013) The last decade of global anthropogenic sulfur dioxide: 2000-2011 emissions. Environ Res Lett 8(1):014003

Koch EW, Barbier EB, Silliman BR et al (2009) Non-linearity in ecosystem services: temporal and spatial variability in coastal protection. Front Ecol Environ 7(1):29-37

Kolka RK, Nelson EA, Trettin CC (2000) Conceptual assessment framework for forested wetland restoration: the Pen Branch experience. Ecol Eng 15:17-21

Kolka RK, Rabenhorst MC, Swanson D (2011a) Chapter 33.2: Histosols. In: Huang PM, Li Y, Sumner ME (eds) Handbook of soil sciences properties and processes, 2nd edn. CRC Press, Boca Raton, pp 33.8-33.29

Kolka RK, Mitchell CP, Jeremiason JD et al (2011b) Mercury cycling in peatland watersheds. CRC Press, Boca Raton, pp 349-370

Kolka R, Trettin C, Tang W et al (2018) Terrestrial wetlands. In: Cavallaro N, Shrestha G, Birdsey R et al (eds) Second state of the carbon cycle report (SOCCR2): a sustained assessment report. U.S. Global Change Research Program, Washington, DC, pp 507-567

Krauss KW, McKee KL, Lovelock CE et al (2014) How mangrove forests adjust to rising sea level. New Phytol 202:19-34

Kunkel KE, Andsager K, Easterling DR (1999) Long-term trends in extreme precipitation events over the conterminous United States and Canada. J Clim 12(8):2515-2527

Kusler J (2006) Developing performance standards for the mitigation and restoration of Northern forested wetlands. The Association of State Wetland Managers, Windham. https://www.aswm.org/pdf_lib/ forested_wetlands_080106.pdf

Laiho R (2006) Decomposition in peatlands: reconciling seemingly contrasting results on the impacts of lowered water levels. Soil Biol Biochem 38(8):2011-2024
Langley JA, McKee KL, Cahoon DR et al (2009) Elevated $\mathrm{CO}_{2}$ stimulates marsh elevation gain, counterbalancing sea-level rise. Proc Natl Acad Sci 106(15):6182-6186

Lellis-Dibble KA, McGlynn KE, Bigford TE (2008) Estuarine fish and shellfish species in U.S. commercial and recreational fisheries: economic value as an incentive to protect and restore estuarine habitat, NOAA Tech. Memo. NMFS-F/SPO-90. U.S. Department of Commerce, Washington, DC, $94 \mathrm{p}$

Li W, Huang H-Z, Zhang Z-N, Wu G-L (2011) Effects of grazing on the soil properties and $\mathrm{C}$ and $\mathrm{N}$ storage in relation to biomass allocation in an alpine meadow. J Soil Sci Plant Nutr 11:27-39

Li Y, Schichtel BA, Walker JT et al (2016) Increasing importance of deposition of reduced nitrogen in the United States. Proc Natl Acad Sci 113(21):5874-5879

Limpens J, Berendse F, Klees H (2004) How phosphorus availability affects the impact of nitrogen deposition on Sphagnum and vascular plants in bogs. Ecosystems 7(8):793-804

Lockaby BG, Walbridge MR (1998) Biogeochemistry. In: Messina MG, Conner WH (eds) Southern forested wetlands: ecology and management. CRC Press, Boca Raton, pp 149-172

Lockaby BG, Stanturf JA, Messina M (1997) Harvesting impacts on functions of forested floodplains: a review of existing reports. For Ecol Manag 90(2-3):93-100

Lowrance R, Altier LS, William RG et al (2000) REMM: the riparian ecosystem management model. J Soil Water Conserv 55:27-34

Lucchese M, Waddington JM, Poulin M et al (2010) Organic matter accumulation in a restored peatland: evaluating restoration success. Ecol Eng 36:482-488

Lugo AE, Brinson M, Brown S (1990) In: Lugo AE, Brinson M, Brown $\mathrm{S}$ (eds) Ecosystems of the world, 15: forested wetlands. Elsevier Science Publishers, Amsterdam, $527 \mathrm{p}$

Lyon EA, Jin Y, Randerson T (2008) Changes in surface albedo after fire inboreal forest ecosystems of interior Alaska assessed using MODIS satellite observations. J Geophys Res 113:G02012

MacFarlane GT, Hebert RA (1984) Effect of oxygen tension, salinity, temperature, and organic matter concentration on the growth and nitrifying activity of an estuarine strain of Nitrosomonas. FEMS Microbiol Lett 23:107-111

MacKenzie RA (2005) Spatial and temporal patterns in insect emergence from a southern Maine salt marsh. Am Midl Nat 153:63-75

MacKenzie RA, Dionne M (2008) Habitat heterogeneity: the importance of salt marsh pools and high marsh surfaces to fish production in two Gulf of Maine salt marshes. Mar Ecol Prog Ser 368:217-230

MacKenzie RA, Dionne M, Miller J et al (2015) Community structure and abundance of benthic infaunal invertebrates in Maine fringing marsh ecosystems. Estuar Coasts 38:1317-1334

MacKenzie RA, Foulk PB, Klump JV et al (2016) Sedimentation and belowground carbon accumulation rates in mangrove forests that differ in diversity and land use: a tale of two mangroves. Wetl Ecol Manag 24:245-261

Magalhães CM, Joye SB, Moreira RM et al (2005) Effect of salinity and inorganic nitrogen concentrations on nitrification and denitrification rates in intertidal sediments and rocky biofilms of the Douro River estuary, Portugal. Water Res 39:1783-1794

Mahan BL, Polasky S, Adams RM (2000) Valuing urban wetlands: a property price approach. Land Econ 76(1):100-113

Mamo TG (2015) Evaluation of the potential impact of rainfall intensity variation due to climate change on existing drainage infrastructure. J Irrig Drain Eng 141(10):05015002

Martin DB, Hartman WA (1987) The effect of cultivation on sediment composition and deposition in prairie pothole wetlands. Water Air Soil Pollut 34:45-53

Marty JT (2005) Effects of cattle grazing on diversity in ephemeral wetlands. Conserv Biol 19:1626-1632 
McGuire AD, Anderson LG, Christensen TR et al (2009) Sensitivity of the carbon cycle in the Arctic to climate change. Ecol Monogr 79:523-555

McKee SE, Aust WM, Seiler JR et al (2012) Long-term site productivity of a tupelo-cypress swamp 24 years after harvesting disturbances. For Ecol Manag 265:172-180

McLean KI, Mushet DM, Renton DA, Stockwell CA (2016a) Aquaticmacroinvertebrate communities of prairie-pothole wetlands and lakes under a changed climate. Wetlands 36(supplement 2):423-435

McLean KI, Mushet DM, Stockwell CA (2016b) From "duck factory" to "fish factory": climate induced changes in vertebrate communities of prairie pothole wetlands and small lakes. Wetlands 36(supplement 2):407-421

Mcleod E, Chmura GL, Bouillon S et al (2011) A blueprint for blue carbon: toward an improved understanding of the role of vegetated coastal habitats in sequestering $\mathrm{CO}_{2}$. Front Ecol Environ 9:552-560

McMurry ST, Belden JB, Smith LM et al (2016) Land use effects on pesticides in sediments of prairie pothole wetlands in North and South Dakota. Sci Total Environ 565:682-689

Megonigal JP, Neubauer SC (2009) Biogeochemistry of tidal freshwater wetlands. In: Perillo GME, Wolanski E, Cahoon DR, Brinson M (eds) Coastal wetlands: an integrated ecosystem approach. Elsevier Science, Amsterdam, pp 535-562

Megonigal JP, Chapman S, Crooks S et al (2016) Impacts and effects of ocean warming on tidal marsh and tidal freshwater forest ecosystems. In: Laffoley D, Baxter JM (eds) Explaining ocean warming: causes, scale, effects and consequences. IUCN, Gland, pp 105-122

Mendelssohn IA, Morris JT (2002) Eco-physiological controls on the productivity of Spartina alterniflora Loisel. In: Weinstein MP, Kreeger DA (eds) Concepts and controversies in tidal marsh ecology. Springer, Dordrecht

Min SK, Zhang XB, Zwiers FW, Hegerl GC (2011) Human contribution to more-intense precipitation extremes. Nature 470(7334):378-381

Minkkinen K, Vasander H, Jauhiainen S et al (1999) Post-drainage changes in vegetation composition and carbon balance in Lakkasuo mire, Central Finland. Plant Soil 207:107-120

Mitsch WJ (1988) Productivity-hydrology-nutrient models of forested wetlands. In: Mitsch WJ, Straškraba M, Jorgensen SE (eds) Wetland modelling. Elsevier, Amsterdam, pp 115-132

Mitsch W, Gosselink J (2015) Wetlands, 5th edn. Wiley, New York

Mitsch WJ, Bernal B, Nahlik AM et al (2013) Wetlands, carbon and climate change. Landsc Ecol 28:583-597

Monks PS, Granier C, Fuzzi S et al (2009) Atmospheric composition change-global and regional air quality. Atmos Environ 43:5268-5350

Montieth DT, Stoddard L, Evans CD et al (2007) Dissolved organic carbon trends resulting from atmospheric deposition chemistry. Nature 450(7169):537-540

Moor H, Hylander K, Norberg J (2015) Predicting climate change effects on wetland ecosystem services using species distribution modeling and plant functional traits. Ambio 44:113-126

Moore TR, Knowles R (1989) The influence of water table levels on methane and carbon dioxide emissions from peatland soils. Can J Soil Sci 69:33-38

Morrissey EM, Gillespie JL, Morina JC, Franklin RB (2014) Salinity affects microbial activity and soil organic matter content in tidal wetlands. Glob Chang Biol 20:1351-1362

Mortsch LD (1998) Assessing the impact of climate change on the Great Lakes shoreline wetlands. Clim Chang 40:391-416

Mueller P, Jensen K, Megonigal P (2016) Plants mediate soil organic matter decomposition in response to sea level rise. Glob Chang Biol 22(1):404-414

Mushet DM, Goldhaber MB, Mills CT et al (2015) Chemical and biotic characteristics of prairie lakes and large wetlands in south-central North Dakota-Effects of a changing climate, U.S. Geological Survey Scientific Investigations Report 2015-5126, 55 p. https:// doi.org/10.3133/sir20155126
Nahlik AM, Fennessy MS (2016) Carbon storage in US wetlands. Nat Commun 7(1):13835. https://doi.org/10.1038/ncomms13835

Narayan S, Beck MW, Wilson P et al (2017) The value of coastal wetlands for flood damage reduction in the Northeastern USA. Sci Rep 7:9463. https://doi.org/10.1038/s41598-017-09269-z

Neaves CM, Aust M, Bolding MC et al (2017a) Loblolly pine (Pinus taeda L.) productivity 23 years after wet site harvesting and site preparation in the lower Atlantic coastal plain. For Ecol Manag 401:207-214

Neaves CM, Aust M, Bolding MC et al (2017b) Soil properties in site prepared loblolly pine (Pinus taeda L.) stands 25 years after wet weather harvesting in the lower Atlantic coastal plain. For Ecol Manag 404:344-353

Nelson LE, Switzer GL, Lockaby BG (1987) Nutrition of Populus deltoides plantations during maximum production. For Ecol Manag 20:25-41

Neubauer SC (2008) Contributions of mineral and organic components to tidal freshwater marsh accretion. Estuar Coast Shelf Sci 78:78-88

Neubauer SC (2014) On the challenges of modeling the net radiative forcing of wetlands: reconsidering Mitsch et al. 2013. Landsc Ecol 29:571-577

Neubauer SC, Givler K, Valentine S, Megonigal JP (2005) Seasonal patterns and plant-mediated controls of subsurface wetland biogeochemistry. Ecology 86:3334-3344

Niemuth ND, Wangler B, Reynolds RE (2010) Spatial and temporal variation in wet area of wetlands in the Prairie Pothole Region of North Dakota and South Dakota. Wetlands 30:1053-1064

Niering WA (1988) Endangered, threatened, and rare wetland plants and animals of the continental United States. In: Hook DD Jr, Smith WHM, Gregory HK et al (eds) The ecology and management of wetlands. Volume 1: The ecology of wetlands. Timber Press, Portlands, pp 227-238

Nixon SW (1980) Between coastal marshes and coastal waters-a review of twenty years of speculation and research on the role of salt marshes in estuarine productivity and water chemistry. In: Hamilton P, MacDonald K (eds) Estuarine and wetland processes. Plenum Press, New York, pp 438-525

Noe GB, Zedler JB (2001) Spatio-temporal variation of salt marsh seedling establishment in relation to the abiotic and biotic environment. J Veg Sci 12:61-74

Nykänen H, Alm J, Silvola J et al (1998) Methane fluxes on boreal peatlands of different fertility and the effect of long-term experimental lowering of the water table on flux rates. Glob Biogeochem Cycles 12:53069

Nykänen H, Vasander H, Huttunen JT, Martikainen PJ (2002) Effect of experimental nitrogen load on methane and nitrous oxide fluxes on ombrotrophic boreal peatland. Plant Soil 242(1):147-155

Odum WE, Odum EP, Odum HT (1995) Nature's pulsing paradigm. Estuaries 18:547-555

Ogle SM, Hunt P, Trettin CC (2014) Chapter 4: Quantifying greenhouse gas sources and sinks in managed wetlands systems. In: Eve M, Pape D, Flugge $\mathrm{M}$ et al (eds) Quantifying greenhouse gas fluxes in agriculture and forestry: methods for entity-scale inventory, Tech. Bull. 139. U.S. Department of Agriculture, Office of the Chief Economist, Washington, DC

Oulehle F, Jones TG, Burden A et al (2013) Soil-solution partitioning of DOC in acid organic soils: results from a UK field acidification and alkalization experiment. Eur J Soil Sci 64(6):787-796

Page SE, Rieley J, Banks CJ (2011) Global and regional importance of the tropical peatland carbon pool. Glob Chang Biol $17: 798-818$

Partain JL Jr, Alden S, Bhatt US et al (2016) An assessment of the role of anthropogenic climate change in the Alaska fire season of 2015. Bull Am Meteorol Soc 97(12):5 p 
Pennock D, Yates T, Bedard-Haughn A et al (2010) Landscape controls on $\mathrm{N}_{2} \mathrm{O}$ and $\mathrm{CH}_{4}$ emissions from freshwater mineral soil wetlands of the Canadian Prairie Pothole region. Geoderma 155:308-319

Pirrone N, Cinnirella S, Feng X et al (2010) Global mercury emissions to the atmosphere from anthropogenic and natural sources. Atmos Chem Phys 10(13):5951-5964

Poffenbarger HJ, Needelman BA, Megonigal JP (2011) Salinity influence on methane emissions from tidal marshes. Wetlands $31: 831-842$

Price JS, Heathwaite AL, Baird AJ (2003) Hydrological processes in abandoned and restored peatlands: an overview of management approaches. Wetl Ecol Manag 11:65-83

Randerson JT, Liu H, Flanner MG et al (2006) The impact of boreal forest fire on climate warming. Science 314:1130-1132

Rasse DP, Peresta G, Drake BG (2005) Seventeen years of elevated $\mathrm{CO}_{2}$ exposure in a Chesapeake Bay Wetland: sustained but contrasting responses of plant growth and $\mathrm{CO}_{2}$ uptake. Glob Chang Biol 11:369-377

Reddy KR Jr, Patrick WH, Lindau CW (1989) Nitrificationdenitrification at the plant root-sediment interface in wetlands. Limnol Oceanogr 34(6):1004-1013

Richards B, Craft CB (2015) Greenhouse gas fluxes from restored agricultural wetlands and natural wetlands, northwestern Indiana. In: Vymazal J (ed) Role of natural and constructed wetlands in nutrient cycling and retention on the landscape. Springer, Cham, pp 17-32

Richardson JL, Vepraskas MJ (eds) (2001) Wetland soils. Lewis Publishers, Boca Raton

Richardson JL, Arndt JL, Montgomery JA (2001) Hydrology of wetland and related soils. In: Richardson JL, Vepraskas MJ (eds) Wetland soils. Lewis Publishers, Boca Raton, pp 35-84

Roberson E (1996) The impacts of livestock grazing on soils and recommendations for management. California Native Plant Society, Sacramento. https://www.cnps.org/cnps/archive/letters/soils.pdf

Rogers K, Saintilan N, Woodroffe CD (2014) Surface elevation change and vegetation distribution dynamics in a subtropical coastal wetland: implications for coastal wetland response to climate change. Estuar Coast Shelf Sci 149:46-56

Rudd JW (1995) Sources of methyl mercury to freshwater ecosystems: a review. Water Air Soil Pollut 80(1):697-713

Sahrawat KL (2004) Organic matter accumulation in submerged soils. Adv Agron 81:169-201

Saintilan N, Wilson NC, Rogers K et al (2014) Mangrove expansion and salt marsh decline at mangrove poleward limits. Glob Chang Biol 20:147-157

Sanders CJ, Maher DT, Tait DR et al (2016) Are global mangrove carbon stocks driven by rainfall? J Geophys Res Biogeosci 121:2600-2609

Sanford T, Wang R, Kenwa A (2015) The age of Alaskan wildfires. Climate Central, Princeton, $32 \mathrm{p}$

Sarukhán J, Whyte A, MA Board of Review (eds) (2005) Ecosystems and human well-being: synthesis. Island Press, Washington, DC

Scavia D, Field JC, Boesch DF et al (2002) Climate change impacts on US coastal and marine ecosystems. Estuaries 25:149-164

Schilling EB, Lockaby GB (2006) Relationships between productivity and nutrient circulation within two contrasting southeastern U.S. floodplain forests. Wetlands 26:181-192

Schimelpfenig DW, Cooper DJ, Chimner RA (2014) Effectiveness of ditch blockage for restoring hydrologic and soil processes in mountain peatlands. Restor Ecol 22:257-265

Schrier-Uijl AP, Kroon PS, Hendriks DMD et al (2014) Agricultural peatlands: towards a greenhouse gas sink-a synthesis of a Dutch landscape study. Biogeosciences 11:4559-4576

Schuur EA, McGuire AD, Schadel C et al (2015) Climate change and the permafrost carbon feedback. Nature 520(7546):171-179

Segarra KEA, Schubotz F, Samarkin V et al (2015) High rates of anaerobic methane oxidation in freshwater wetlands reduce potential atmospheric methane emissions. Nat Commun 6:7477
Shelby JD, Chescheir GM, Skaggs RW, Amatya DM (2005) Hydrologic and water-quality response of forested and agricultural lands during the 1999 extreme weather conditions in eastern North Carolina. Trans Am Soc Agric Biol Eng 48(6):2179-2188

Shurr EAG, McGuire D, Romanovsky V et al (2018) Chapter 11: Arctic and boreal carbon. In: Cavallaro N, Shrestha G, Birdsey R et al (eds) Second state of the carbon cycle report: a sustained assessment report. U.S. Global Change Research Program, Washington, DC, pp 428-468

Simpson L, Osborne T, Duckett L, Feller I (2017) Carbon storages along a climate induced coastal wetland gradient. Wetlands 37(6):1023-1035

Skaggs RW, Bravé MA, Gilliam JW (1994) Impacts of agricultural drainage on water quality. Crit Rev Environ Sci Technol 24(1):1-32

Skaggs RW, Tian S, Chescheir GM et al (2016) Forest drainage. In: Amatya et al (eds) Forest hydrology: processes, management and assessment. CABI Publishers, Wallingford, pp 124-140

Smil V (2000) Phosphorus in the environment: natural flows and human interferences. Annu Rev Energy Environ 25:53-88

Smith KA, Ball T, Conen F et al (2003) Exchange of greenhouse gases between soil and atmosphere: interactions of soil physical factors and biological processes. Eur J Soil Sci 54:779-791

Snedaker SC (1995) Mangroves and climate change in the Florida and Caribbean region: scenarios and hypotheses. In: Asia-Pacific symposium on mangrove ecosystems. Springer, Dordrecht, pp 43-49

Spaulding MD, Ruffo S, Lacambra C et al (2014) The role of ecosystems in coastal protection: adapting to climate change and coastal hazards. Ocean Coast Manag 90:50-57

Springer KB, Manker CR, Pigati JS (2015) Dynamic response of desert wetlands to abrupt climate change. Quat Int 387:145-146

St. Louis VL, Rudd JW, Kelly CA et al (1994) Importance of wetlands as sources of methylmercury to boreal forest ecosystems. Can J Fish Aquat Sci 51(5):1065-1076

St. Louis VL, Rudd JW, Kelly CA et al (1996) Production and loss of methylmercury and loss of total mercury from boreal forest catchments containing different types of wetlands. Environ Sci Technol 30(9):2719-2729

Stehr G, Böttcher B, Dittberner P et al (1995) The ammonia-oxidizing, nitrifying population of the River Elbe estuary. FEMS Microbiol Ecol 17:177-186

Stelk MJ, Christie J, Weber R et al (2017) Wetland restoration: contemporary issues and lessons learned. Association of State Wetland Managers, Windham

Stewart RE, Kantrud HA (1972) Vegetation of prairie potholes, North Dakota, in relation to quality of water and other environmental factors, Professional Paper 585-D. U.S. Geological Survey, Washington, DC. https://doi.org/10.3133/pp585D

Strack M, Zuback YCA (2013) Annual carbon balance of a peatland 10 yr following restoration. Biogeosciences 10:2885-2896

Stromberg JC, Anderson DC, Scott ML (2012) Riparian floodplain wetlands of the arid and semiarid Southwest. In: Batzer DP, Baldwin $\mathrm{AH}$ (eds) Wetland habitats of North America: ecology and conservation concerns. University of California Press, Berkeley

Sutton-Grier AS, Megonigal JP (2011) Plant species traits regulate methane production in freshwater wetland soils. Soil Biol Biochem 43(2):413-420

Tangen BA, Gleason RA (2008) Reduction of sedimentation and nutrient loading. In: Gleason RA, Laubhan MK, Euliss NH Jr (eds) Ecosystem services derived from wetland conservation practices in the United States Prairie Pothole Region with an emphasis on the U.S. Department of Agriculture Conservation Reserve and Wetlands Reserve Programs, Professional Paper 1745. U.S. Department of the Interior, Geological Survey, Reston, $58 \mathrm{p}$

Tangen BA, Finocchiaro RG, Gleason RA (2015) Effects of land use on greenhouse gas fluxes and soil properties of wetland catchments in the Prairie Pothole Region of North America. Sci Total Environ 533:391-409 
Tiner RW (1999) Wetland indicators. CRC Press, Boca Raton

Trettin CC, Jurgensen MF (2003) Carbon cycling in wetland forest soils. In: Kimble JM, Heath LS, Birdsey RA, Lal R (eds) The potential of US forest soils to sequester carbon and mitigate the greenhouse effect. CRC Press, Boca Raton, pp 311-332

Trettin CC, Song B, Jurgensen MF, Li C (2001) Existing soil carbon models do not apply to forested wetlands, Gen. Tech. Rep. SRS-46. U.S. Department of Agriculture, Forest Service, Southern Research Station, Asheville, $10 \mathrm{p}$

Trettin CC, Jurgensen MF, Gale MR, McLaughlin JW (2011) Carbon and nutrient pools in a northern forested wetland 11 years after harvesting and site preparation. For Ecol Manag 262:1826-1833

Trimble SW (1974) Man-induced soil erosion on the southern Piedmont 1700-1970. Soil and Water Conservation Society, Ankeny

Turetsky MR, Manning SW, Wieder RK (2004) Dating recent peat deposits. Wetlands 24:324-356

Turetsky MR, Donahue WF, Benscoter BW (2011) Experimental drying intensifies burning and carbon losses in a northern peatland. Nat Commun 2:1-5

Turetsky MR, Kotowska A, Bubier J et al (2014) A synthesis of methane emissions from 71 northern, temperate, and subtropical wetlands. Glob Chang Biol 20(7):2183-2197

Turner RE, Swenson EM, Milan CS (2000) Organic and inorganic contributions to vertical accretion in salt marsh sediments. In: Weinstein M, Kreeger DA (eds) Concepts and controversies in tidal marsh ecology. Kluwer Academic Publishing, Dordrecht, pp 583-595

Turunen J, Roulet NT, Moore TR, Richard PJ (2004) Nitrogen deposition and increased carbon accumulation in ombrotrophic peatlands in eastern Canada. Glob Biogeochem Cycles 18(3):GB3002

U.S. Environmental Protection Agency [US EPA] (2015) Section 404 of the Clean Water Act and swampbuster: wetlands on agricultural lands. https://www.epa.gov/cwa-404/section-404-and-swampbuster-wetlands-agricultural-lands. Accessed 18 Jan 2019

U.S. Environmental Protection Agency [US EPA] (2016) National wetland condition assessment 2011: a collaborative survey of the nation's wetlands. EPA Report EPA-843-R-15-005. Washington, DC: U.S. Environmental Protection Agency, Office of Wetlands, Oceans and Watersheds; Office of Research and Development. https://www.epa.gov/national-aquatic-resource-surveys/nwca

U.S. Fish and Wildlife Service \# [US FWS] (2011) Status and trends of wetlands in the conterminous United States 2004 to 2009, Report to Congress (https://www.fws.gov/wetlands/status-and-trends/)

van der Kamp G, Hayashi M (1998) The groundwater recharge function of small wetlands in the semi-arid northern prairies. Freshwater functions and values of prairie wetlands. Great Plains Res 8(1):39-56

van der Kamp G, Stolte WJ, Clark RG (1999) Drying out of small prairie wetlands after conversion of their catchments from cultivation to permanent brome grass. Hydrol Sci J 44:387-397

van der Kamp G, Hayashi M, Gallén D (2003) Comparing the hydrology of grassed and cultivated catchments in the semi-arid Canadian prairies. Hydrol Process 17:559-575

Vann CD, Megonigal JP (2003) Elevated $\mathrm{CO}_{2}$ and water depth regulation of methane emissions: comparison of woody and non-woody wetland plant species. Biogeochemistry 63:117-134

Vasilas LM, Hurt GW, Berkowitz JF (eds) (2016) Field indicators of hydric soils in the United States, Version 8.0. U.S. Department of Agriculture, Natural Resources Conservation Service, Washington, DC, $55 \mathrm{p}$

Venne LS, Anderson TA, Zhang B et al (2008) Organochlorine pesticide concentrations in sediment and amphibian tissue in playa wetlands in the southern High Plains, USA. Bull Environ Contam Toxicol 80:497-501

Vepraskas MJ (1996) Redoximorphic features for identifying aquic conditions, Tech. Bull. 301. North Carolina State University, Agricultural Research Service, Raleigh
Vepraskas MJ, Craft CB (2016) Wetland soils, genesis hydrology and classification, 2nd edn. CRC Press, Boca Raton

Vepraskas MJ, Faulkner SP (2001) Redox chemistry of hydric soils. In: Richardson JL, Vepraskas MJ (eds) Wetland soils. Lewis Publishers, Boca Raton, pp 85-106

Verry ES (1997) Hydrological processes of natural northern forested wetlands. In: Trettin CC, Jurgensen MF, Grigal DF, Gale MR, Jeglum JK (eds) Northern forested wetlands: ecology and management. CRC Press, Boca Raton, pp 163-188

Vet R, Artz RS, Carou S (2014) A global assessment of precipitation chemistry and deposition of sulfur, nitrogen, sea salt, base cations, organic acids, acidity and $\mathrm{pH}$, and phosphorus. Atmos Environ 93:3-100

Vile MA, Bridgham SD, Wieder RK, Novák M (2003) Atmospheric sulfur deposition alters pathways of gaseous carbon production in peatlands. Glob Biogeochem Cycles 17(2):1058

Vose RS, Easterling DR, Kunkel KE et al (2017) Temperature changes in the United States. In: Wuebbles DJ, Fahey DW, Hibbard KA et al (eds) U.S. Global Change Research Program. Climate science special report: fourth national climate assessment, vol I. U.S. Global Change Research Program, Washington, DC, pp 185-206

Vymazal J (2011) Constructed wetlands for wastewater treatment: five decades of experience. Environ Sci Technol 45(1):61-69

Waddington JM, Morris PJ, Kettridge N et al (2015) Hydrological feedbacks in northern peatlands. Ecohydrolology 8:113-127

Walsh J, Wuebbles D, Hayhoe K et al (2014) Chapter 2: our changing climate. In: Mellilo JM, Richmond TC, Yohe GW (eds) Impacts in the United States: the third national climate assessment. U.S. Global Change Research Program, Washington, DC, pp 19-67

Wear DN, Greis JG (eds) (2002) Southern forest resource assessment, General Technical Report SRS-GTR-53. U.S. Department of Agriculture, Forest Service, Southern Research Station, Asheville, $635 \mathrm{p}$

Weiss-Penzias PS, Gay DA, Brigham ME et al (2016) Trends in mercury wet deposition and mercury air concentrations across the US and Canada. Sci Total Environ 15(568):546-556

Weston NB, Dixon RE, Joye SB (2006) Ramifications of increased salinity in tidal freshwater sediments: geochemistry and microbial pathways of organic matter mineralization. J Geophys Res 111:G01009

Weston NB, Vile MA, Neubauer SC, Velinsky DJ (2011) Accelerated microbial organic matter mineralization following salt-water intrusion into tidal freshwater marsh soils. Biogeochemistry 102:135-151

Wickland KP, Krusche AV, Kolka RK et al (2014) Chapter 5: Inland wetland mineral soils. In: Hiraishi T, Krug T, Tanabe K et al (eds) Intergovernmental panel on climate change supplement to the 2006 guidelines for national greenhouse gas inventories: wetlands. Intergovernmental Panel on Climate Change, Geneva

Windham-Myers L, Cai WJ, Megonigal P et al (2018) Chapter 15: Tidal wetlands and estuaries. In: Cavallaro N, Shrestha G, Birdsey R et al (eds) Second state of the carbon cycle report (SOCCR2): a sustained assessment report. U.S. Global Change Research Program, Washington, DC

Winter TC (1988) A conceptual framework for assessing cumulative impacts on hydrology of nontidal wetlands. Environ Manag 12:605-620

Winter TC (1989) Hydrologic studies of wetlands in the northern prairie. In: van der Valk AG (ed) Northern prairie wetlands. Iowa State University Press, Ames, pp 193-211

Winter TC, Rosenberry DO (1998) Hydrology of prairie pothole wetlands during drought and deluge: a 17-year study of the cottonwood Lake wetland complex in North Dakota in the perspective of longer term measured and proxy hydrological records. Clim Chang 40:189-209

Winter TC, Woo MK (1990) Hydrology of lakes and wetlands. In: Wolman MG, Riggs HC (eds) The geology of North America, 
Vol. 1: Surface water hydrology. Geological Society of America, Boulder, pp 159-187

Woo MK (1992) Impacts of climate variability and change on Canadian wetlands. Can Water Resour J 17:63-69

Woodward RT, Wui Y (2001) The economic value of wetland services: a meta-analysis. Ecol Econ 37(2):257-270

Wüst-Galley C, Mössinger E, Leifeld J (2016) Loss of the soil carbon storage function of drained forested peatlands. Mires Peat 18:1-22

Young PJ, Keeland BD, Sharitz RR (1995) Growth response of bald cypress to an altered hydrologic regime. Am Midl Nat 133:206-212

Young AM, Higuera PE, Duffy PA, Hu FS (2016) Climatic thresholds shape northern high-latitude fire regimes and imply vulnerability to future climate change. Ecography 39:1-12
Yu K, Faulkner SP, Baldwin MJ (2008) Effect of hydrologic conditions on nitrous oxide emissions, methane and carbon dioxide dynamics in a bottomland hardwood forest and its implications for carbon sequestration. Glob Chang Biol 14:798-812

Zhang Y, Li C, Trettin CC et al (2002) An integrated model of soil, hydrology, and vegetation for carbon dynamics in wetland ecosystems. Glob Chang Biol 16(4):1061

Zillioux EJ, Porcella DB, Benoit JM (1993) Mercury cycling and effects in freshwater wetland ecosystems. Environ Toxicol Chem 12(12):2245-2264

Zoltai SC, Morrissey LA, Livingston GP, de Groot WJ (1998) Effects of fires on carbon cycling in North American boreal peatlands. Environ Rev 6:13-24

Open Access This chapter is licensed under the terms of the Creative Commons Attribution 4.0 International License (http://creativecommons. org/licenses/by/4.0/), which permits use, sharing, adaptation, distribution and reproduction in any medium or format, as long as you give appropriate credit to the original author(s) and the source, provide a link to the Creative Commons license and indicate if changes were made.

The images or other third party material in this chapter are included in the chapter's Creative Commons license, unless indicated otherwise in a credit line to the material. If material is not included in the chapter's Creative Commons license and your intended use is not permitted by statutory regulation or exceeds the permitted use, you will need to obtain permission directly from the copyright holder. 